\title{
SUPERCLEAN COAL-WATER SLURRY COMBUSTION TESTING IN AN OIL-FIRED BOILER
}

Semiannual Technical Progress Report
for the Period 08/15/1992 to 02/15/1993

$\mathrm{DOE} / \mathrm{PC} / 88697--\mathrm{T} 7$

DE93 013058

By

Bruce G. Miller, Co-Principal Investigator

Sarma V. Pisupati, Research Associate

Roger L. Poe, Research Assistant

Joel L. Morrison, Research Assistant

Jiangyang Xie, Graduate Research Assistant

Peter M. Walsh, Faculty Associate

Ronald T. Wincek, Research Assistant

David A. Clark, Research Assistant

Alan W. Scaroni, Project Manager

April 21, 1993

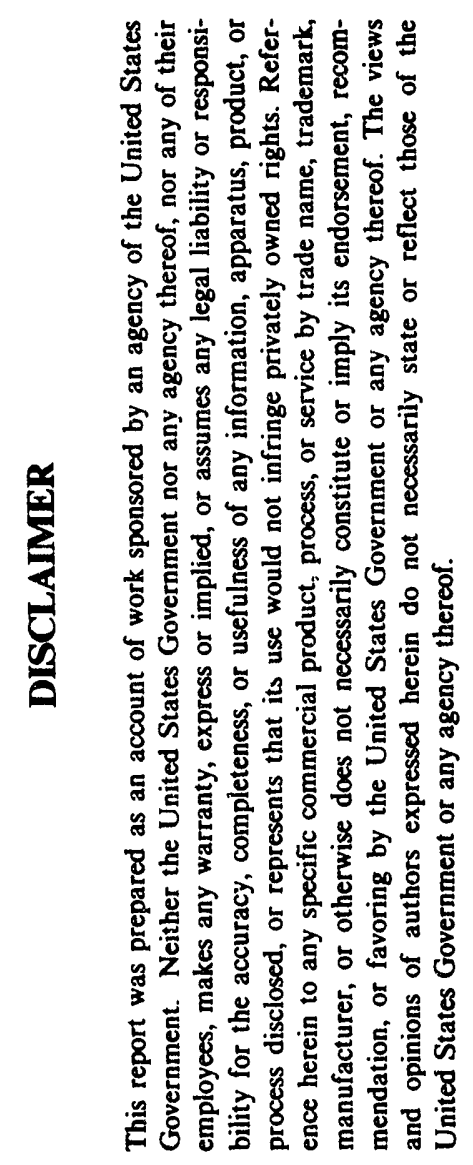

Work Performed Under Cooperative Agreement No. DE-FC22-89PC88697

For

U.S. Department of Energy

Pittsburgh Energy Technology Center

Pittsburgh, Pennsylvania

By

Energy and Fuels Research Center

The Pennsylvania State University

University Park, Pennsylvania 


\section{DISCLAIMER}

This report was prepared as an account of work sponsored by the United States Government. Neither the United States Government nor the United States Department of Energy, nor any of their employees, nor any of their contractors, subcontractors, or their employees makes any warranty, express or implied, or assumes any legal liability or responsibility for the accuracy, completeness, or usefulness of any information, apparatus, product, or process disclosed, or represents that its use would not infringe privately owned rights. 
$1.0 \quad$ INTRODUCTION $\quad$...................................................................

2.0 PHASE I: DESIGN, PERMITTING, AND

TEST PLANNING ……………...........................................

2.1 Task 3. Identify Operating Procedures ……………...................... 3

2.1.1 Boiler Water Treatment ................................................... 3

2.1.2 Emissions Monitoring ................................................... 17

3.0 PHASE II: CONSTRUCTION AND START UP .............................. 22

3.1 Task 2. SCCWS Preparation ...................................................... 22

4.0 PHASE III: DEMONSTRATION AND EVALUATION $\quad$................ 28

4.1 Task 1. Test Burn …………............................................... 28

4.1.1 Subtask 1a. SCCWS Combustion Performance ........... 28

4.1.2 Subtask 1b. Slagging/Fouling Propensit28 Corrosion Characteristics $\quad$............................................ $\quad 38$

4.1.3 Subtask 1c. Erosion Characteristics ............................ 44

4.2 Task 2. Economic Evaluation ................................................. 48

4.3 Task 3. Complete Project Report ............................................... 55

5.0 PHASE IV: ADVANCED SYSTEM TESTS ................................. 55

5.1 Task 1. Procure and Install a Burner and Superheater ................... 55

5.2 Task 2. Construct a SCCWS Preparation Facility ........................ 56

5.3 Task 5. Install an Advanced Flue Gas Treatment System ............. 56

6.0 MISCELLANEOUS ACTIVITIES …………......................................... 56

7.0 NEXT SEMIANNUAL PERIOD ACTIVITIES ....................................... 60

8.0 REFERENCES

9.0 ACKNOWLEDGMENTS …............................................................. 61






\subsection{INTRODUCTION}

The Pennsylvania State University is conducting a superclean coal-water slurry (SCCWS) program for the United States Department of Energy (DOE) and the Commonwealth of Pennsylvania with the objective of determining the capability of effectively firing SCCWS in an industrial boiler designed for heavy fuel oil. Penn State has entered into a cooperative agreement with DOE to determine if SCCWS (a fuel containing coal with $3.0 \mathrm{wt} . \%$ ash and $0.9 \mathrm{wt} . \%$ sulfur) can effectively be burned in a heavy fuel oil-designed industrial boiler without adverse impact on boiler rating, maintainability, reliability, and availability. The project will provide information on the design of new systems specifically configured to fire these clean coal-based fuels. The project consists of four phases: (1) design, permitting, and test planning, (2) construction and start up, (3) demonstration and evaluation (1,000-hour demonstration), and (4) program expansion (additional 1,000 hours of testing). The boiler testing will determine if the SCCWS combustion characteristics, heat release rate, fouling and slagging behavior, corrosion and erosion limits, and fuel transport, storage, and handling characteristics can be accommodated in an oil-designed boiler system. In addition, the proof-of-concept demonstration will generate data to determine how the properties of SCCWS and its parent coal affect boiler performance. Economic factors associated with retrofitting boilers will be identified.

The project consists of four phases as previously mentioned. Foilowing is an outline of the project tasks that comprise the four phases:

Phase I: Design, Permitting, and Test Planning

Task 1. Design

Task 2. Permitting

Task 3. Test Planning

Phase II: Construction and Start Up

Task 1. Host Site Readiness/Boiler Retrofit

Task 2. SCCWS Preparation

Task 3. Performance Prediction

Task 4. Shakedown Testing

Phase III: Demonstration and Evaluation

Task 1. Test Burn

Subtask 1.a. SCCWS combustion performance

Subtask 1.b. Slagging/fouling propensity; corrosion characteristics

Subtask 1.c. Erosion characteristics

Subtask 1.d. Fuel transport, storage, and handling characteristics

Task 2. Evaluate Retrofit Economics

Task 3. Project Report 


\section{Phase IV: Advanced System Tests}

Task 1. Burner/Superheater Procurement/Installation

Task 2. SCCWS Preparation Facility

Task 3. Flue Gas Treatment System

Task 4. 1,000-Hour Test

Task 5. Final Report

Penn State began a coal-water fuel (CWF) research and development program in 1984 with the ultimate goal of facilitating the replacement of petroleum-based fuels with coal-based fuels in fuel oil-fired (designed) boilers. The Pennsylvania legislature appropriated funds in 1984 for the construction of a demonstration CWF boiler with a capacity of approximately $15,000 \mathrm{lb}$ steam $/ \mathrm{h}$ on the main campus of Penn State at University Park. The project goal was to conduct a demonstration of the use of CWF, derived from Pennsylvania coal, in an environmentally acceptable manner, while evaluating the effects on boiler performance of long-term firing with CWF. From a commercialization viewpoint, the motivation for the project was to demonstrate the technical feasibility of retrofitting existing fuel oil-fired units to burn CWF, particularly in the commercial and light-industrial sectors. Funding each year since 1984 has allowed for fuel procurement and the installation of a nominally rated $1,000 \mathrm{lb} \mathrm{steam} / \mathrm{h}$ (maximum firing rate of 2 million Btu/h) Cleaver-Brooks A-frame watertube boiler [1] to investigate: the effect of boiler operating parameters on combustion performance [2]; automation of the firing of slurry fuels, particularly with respect to start up and shutdown procedures but also for optimizing boiler performance [3]; testing candidate CWFs; and [4] providing the necessary research support and training prior to start up of the demonstration unit. The SCCWS demonstration program is being conducted on the $15,000 \mathrm{lb}$ steam/h demonstration boiler.

The approach being used to achieve the objectives of the program is as follows:

1. Install a natural gas/fuel oil-designed package boiler and generate baseline data firing natural gas.

2. Shake down the system with SCCWS and begin the first 1,000 hours of testing using the burner/atomizer system provided with the boiler. The first 1,000-hour demonstration will consist of boiler optimization testing and the combustion performance will be evaluated using SCCWS preheat, varying atomizing air pressure (up to 200 psig as compared to the 100 psig boiler manufacturer design pressure), and using steam as the atomizing medium.

3. If the combustion performance is not acceptable based on the optimized combustion efficiency and/or the level of gas support required for flame stability, then low-cost modifications, such as installing a quarl and testing alternate atomizers, will be implemented. 
4. If acceptable combustion performance is not obtained with the low-cost modifications, then the first phase of the demonstration will be terminated and the burner system replaced with one of proven CWF design.

5. In addition to the advanced burner system, a superheater tube and advanced flue gas cleanup system will be installed and the second 1,000-hour demonstration will be conducted.

The first three steps (i.e., the first demonstration) have been completed and the combustion performance of the burner that was provided with the boiler has been determined to be unacceptable. Consequently, the first demonstration was concluded at approximately 500 hours of firing. This report summarizes the results for this semiannual period and a complete synopsis will be presented in a project report (which is currently being prepared) detailing Phases I through III. The second demonstration (Phase IV) will be conducted after a proven CWFdesigned burner has been installed on the boiler.

Accomplishments this period are presented in Sections 2.0, 3.0, 4.0, 5.0, and 6.0 for Phases I, II, III, IV, and miscellaneous activities, respectively. Section 7.0 outlines the activities planned for the next semiannual period. References are contained in Section 8.0 and acknowledgments are given in Section 9.0. The status of the project schedule is given in Figures 1 through 6, with a description of the milestones contained in Table 1.

\subsection{PHASE I: DESIGN, PERMITTING, AND TEST PLANNING}

Phase I was completed with the preparation of operating procedures for conducting boiler water analysis and emission monitoring (see Section 2.1). These results, along with the operating procedures previously reported $[5,6]$, will be incorporated into an operating manual upon conclusion of the program.

\subsection{Task 3. Identifying Operating Procedures}

Operating procedures for various system components were documented this reporting period for boiler water treatment and emissions monitoring.

\subsubsection{Boiler Water Treatment}

\section{System Overview}

The water that is used for steam production must be treated to prevent corrosion, scaling, and contamination of the steam. This requires treating the raw water added to the system and conditioning the water present in the boiler.

The first step in this process, softening the water through the removal of hardness (calcium and magnesium ions), is accomplished in water softeners located in the adjacent East Campus Steam Plant. Once softened, the water is then piped to an 8,500 gallon deaerator tank 

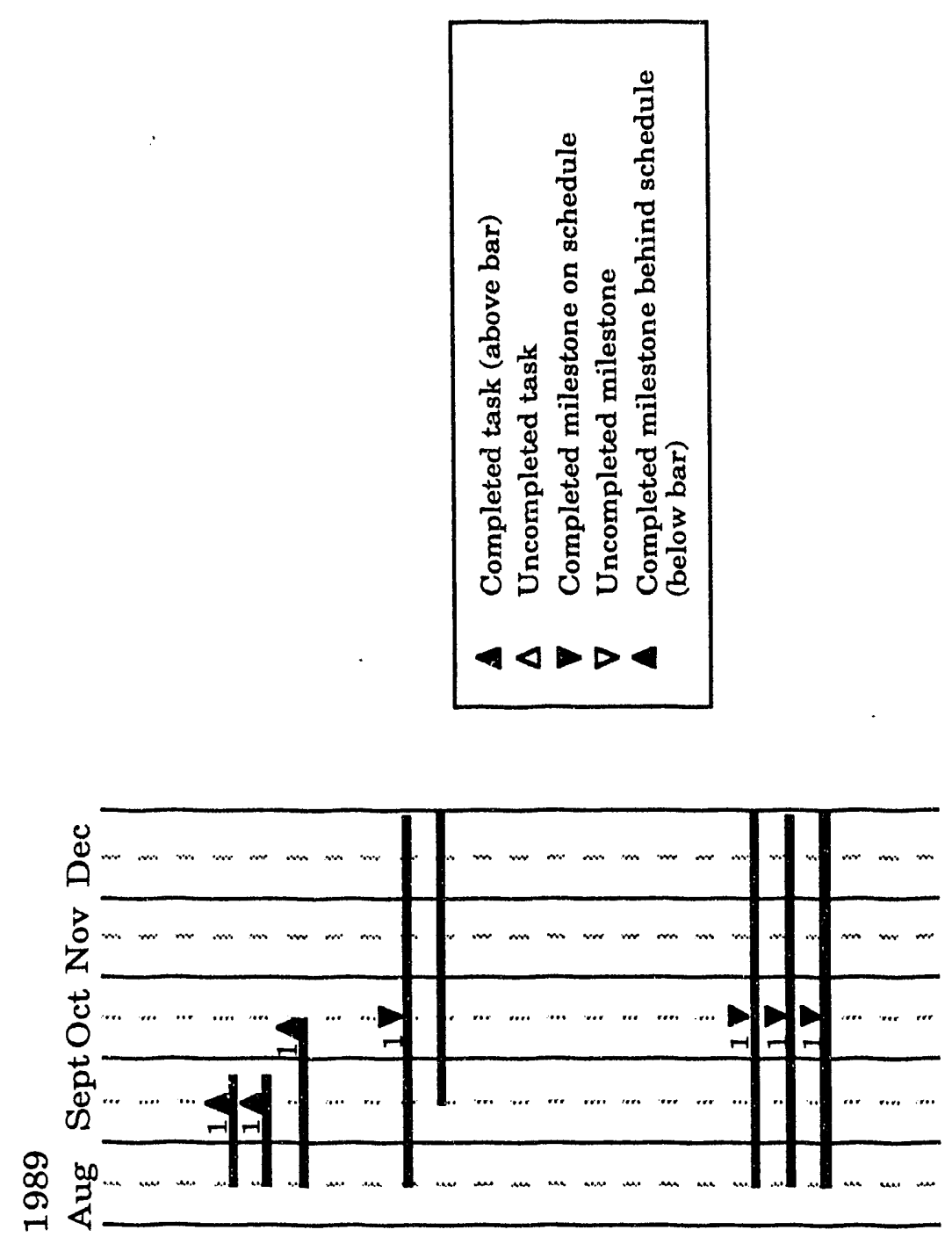

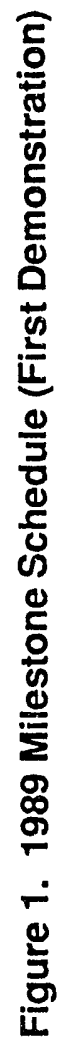

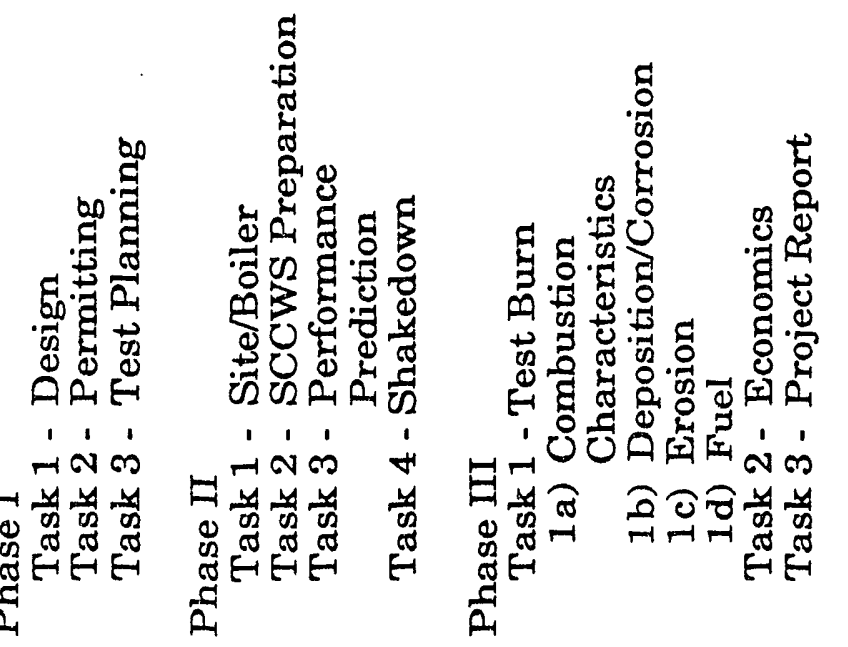




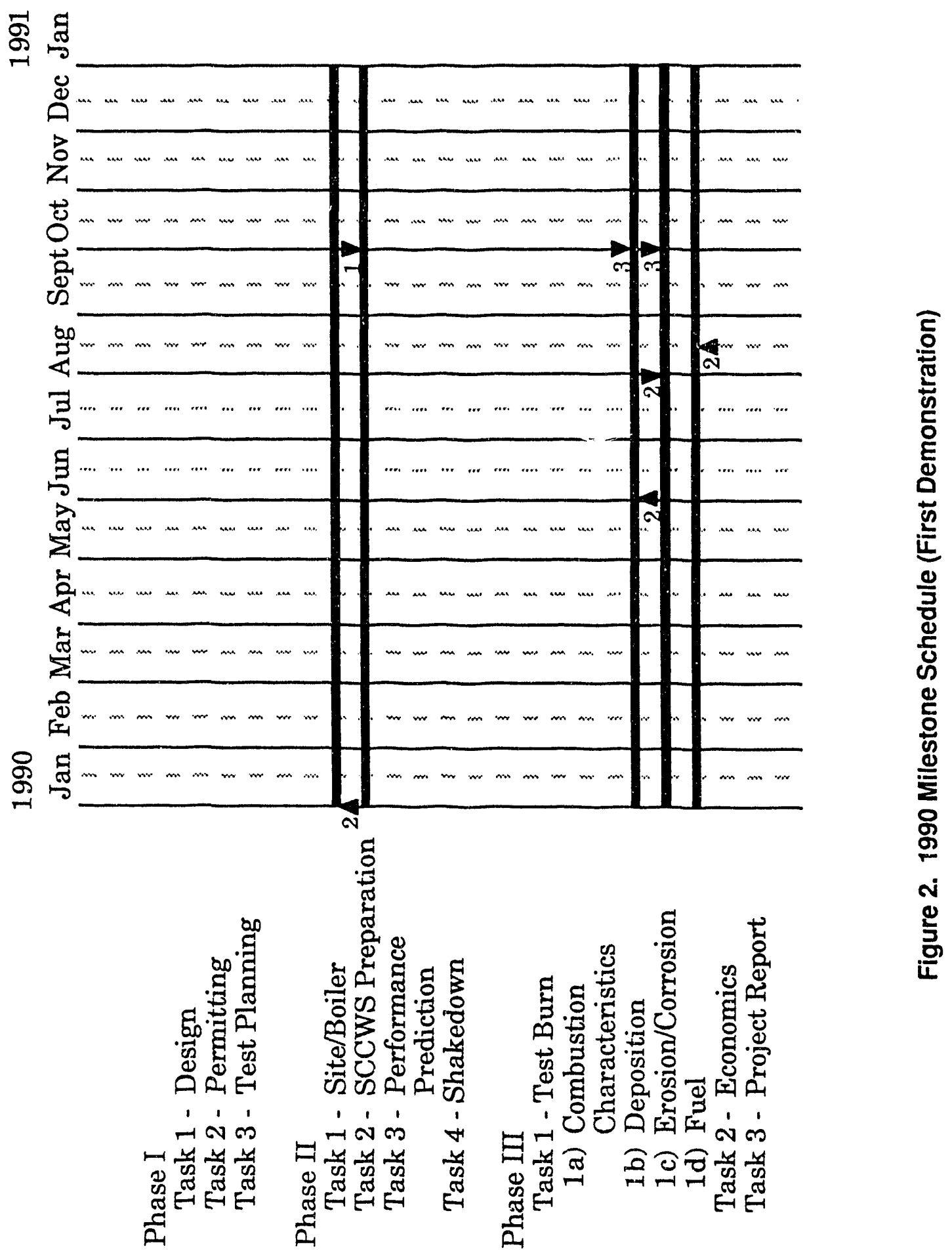




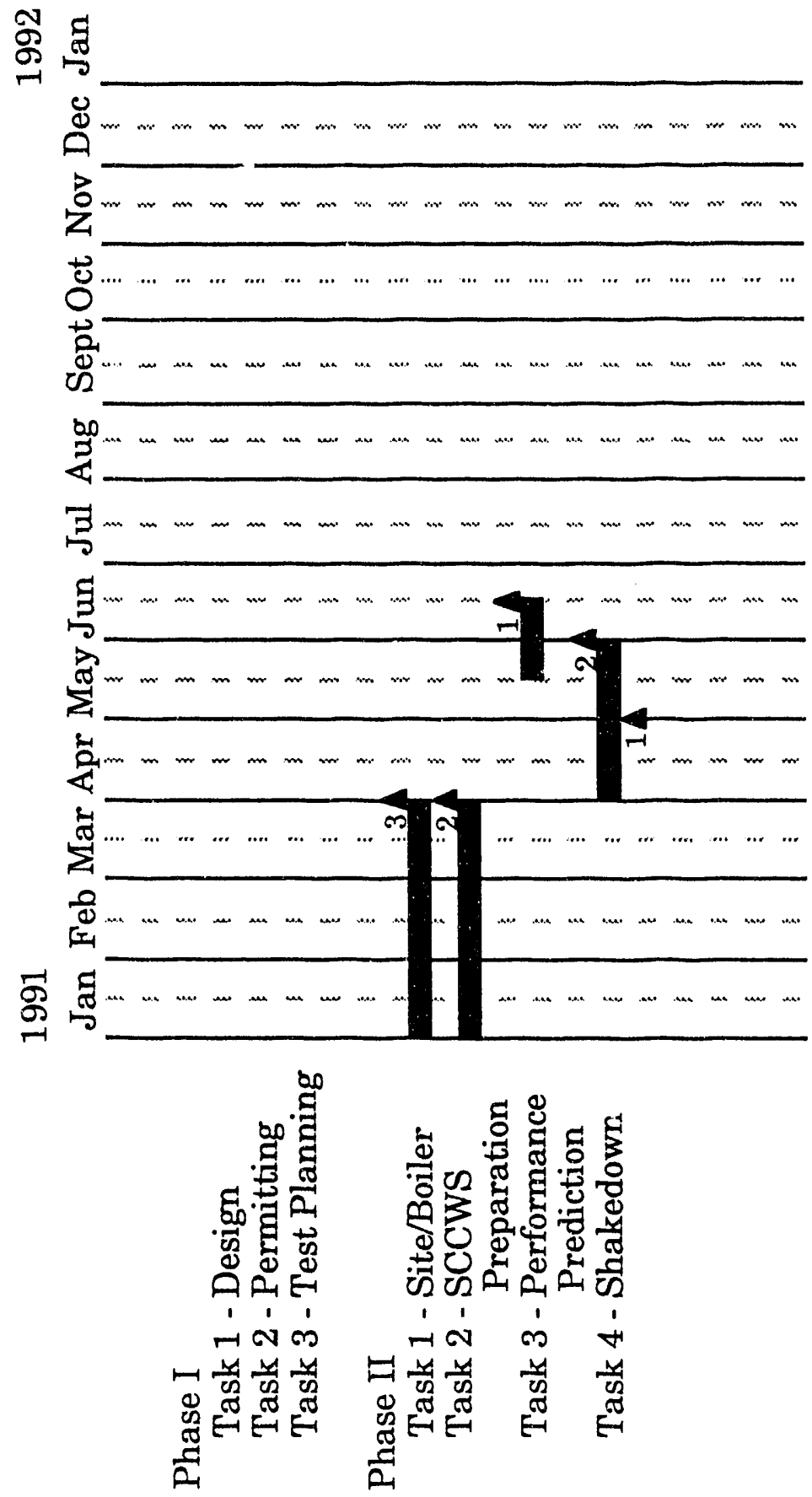




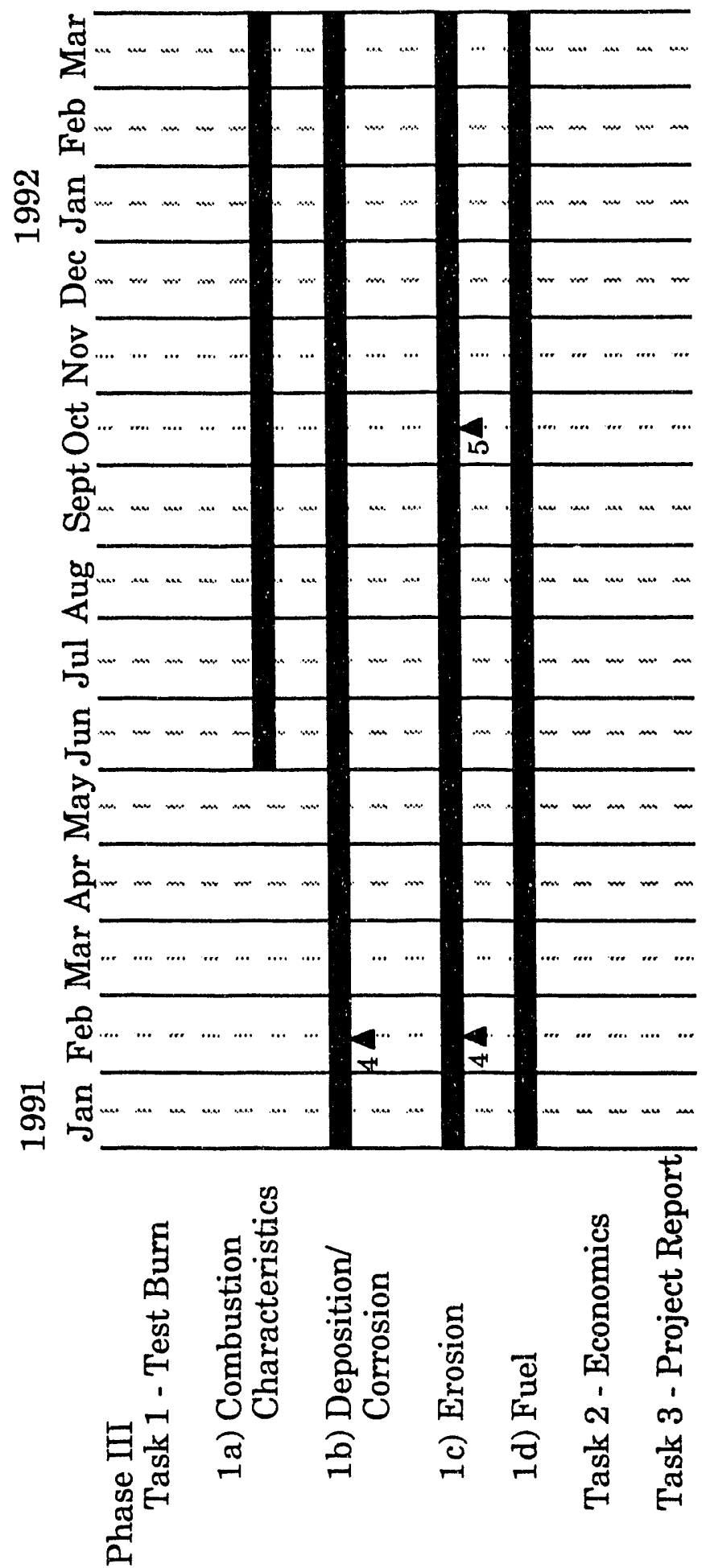









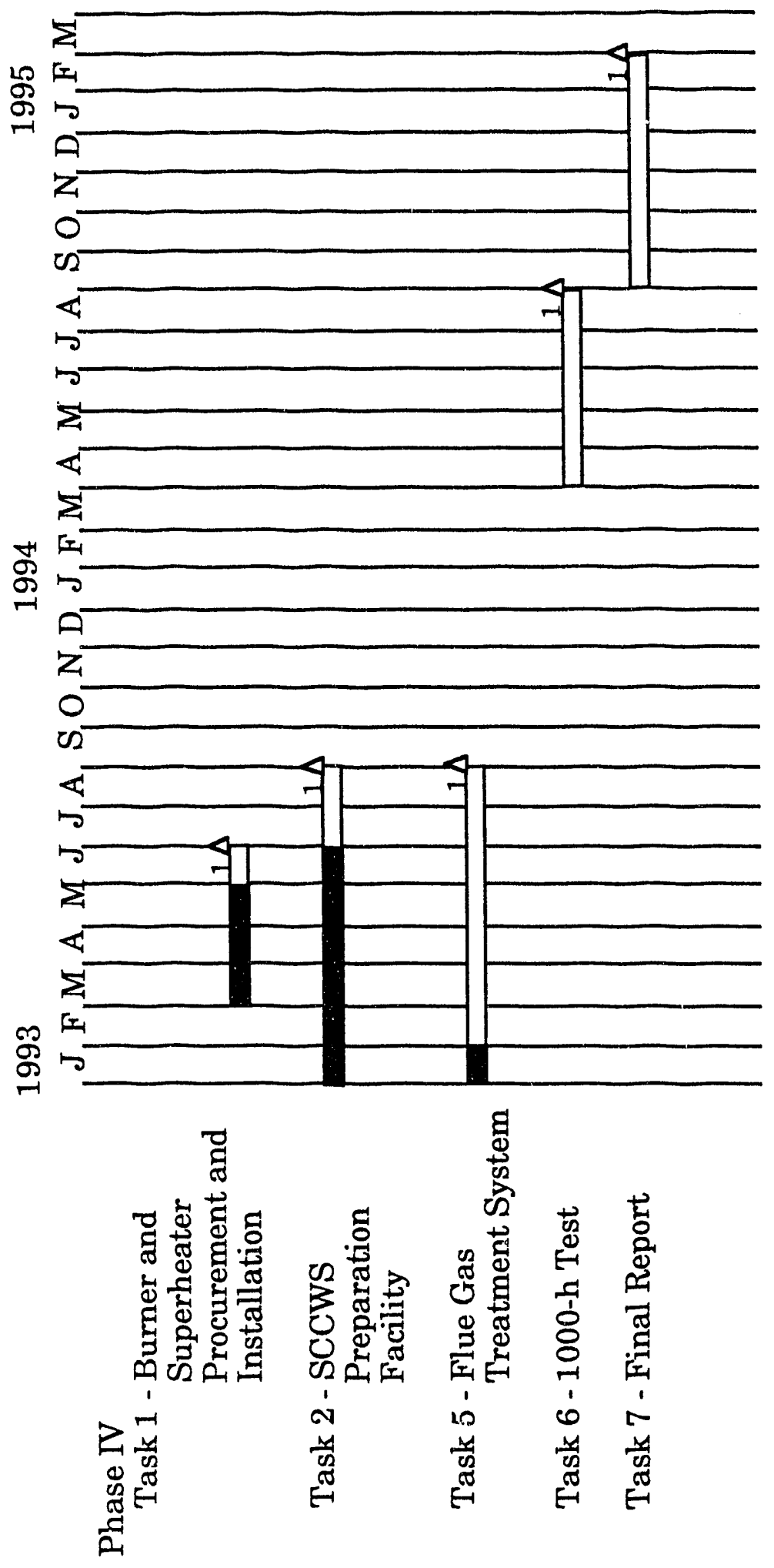




Table 1. Milestone Description

Milestone

Phase I

Task 1, No. 1

Task 2, No. 1

Task 3, No. 1

\section{Phase II}

Task 1, No. 1

Task 1, No. 2

Task 1, No. 3

Task 2, No. 1

Task 2, No. 2

Task 3, No. 1

Task 4, No. 1

Task 4, No. 2

\section{Phase III}

Task 1, No. 1

Subtask 1a, No. 1

Subtask 1a, No. 2

Subtask 1a, No. 3

Subtask $1 \mathrm{~b}$, No. 1

Subtask 1b, No. 2

Subtask 1b, No. 3

Subtask 1b, No. 4

Subtask 1b, No. 5

Subtask 1b, No. 6

Subtask 1b, No. 7

Subtask 1c, No. 1

Subtask 1c, No. 2

Subtask 1c, No. 3

Subtask 1c, No. 4

Subtask 1c, No. 5

Subtask 1c, No. 6

Subtask 1d, No. 1

Subtask 1d, No. 2

Subtask 1d, No. 3

Task 2, No. 1

Task 3, No. 1

\section{Description}

Identify equipment and diagnostic instrumentation

Review present permit

Develop SCCWS specifications, identify operating

procedures, prepare detailed test plan

Building/boiler construction and installation let for bids

Building/boiler construction and installation awarded

Prepare site, install boiler and auxiliary equipment

Identify coal for SCCWS preparation

Prepare SCCWS for demonstration

Predict boiler performance

Shakedow $r_{i}$ boiler and auxiliary equipment

Generate baseline data on gas

Perform demonstration

300-hour demonstration milestone

500-hour demonstration milestone

Redefine SCCWS specifications

Develop deposition and corrosion test plan

Design suction pyrometer

Construct suction pyrometer

Deposition characterization equipment design and specification

Acquisition of baseline data for spectroscopic analysis of deposits; acquisition of baseline data for corrosion of tubes by ash components

Coupon testing in boiler

Complete deposition and corrosion testing

Develop erosion test plan

Complete research boiler erosion evaluation

Full-scale erosion technique decision

Design probe for full-scale erosion study

Construct erosion probe

Complete erosion modeling

Identify viscometer

Complete preliminary viscosity and stability tests

Complete viscosity and stability tests

Complete economic evaluation

Complete project report

Procure and install bumer and superheater

Complete construction of SCCWS preparation facility

Install flue gas treatment system

Complete 1,000-hr test

Complete final report
Planned

Completion

Date

Actual

Completion

Date

$09 / 15 / 89$

$09 / 15 / 89$

$09 / 15 / 89$

$09 / 15 / 89$

$10 / 15 / 89$

$02 / 15 / 93$

$10 / 18 / 89$

$10 / 18 / 89$

$12 / 31 / 89$

04/01/91

09/30/90

$04 / 01 / 91$

$06 / 15 / 91$

$04 / 31 / 91$

$05 / 31 / 91$

$07 / 31 / 92$

$10 / 31 / 92$

$01 / 15 / 93$

$10 / 15 / 89$

$06 / 01 / 90$

10/01/90

$01 / 01 / 91$

$08 / 31 / 91$

$03 / 23 / 90$

$01 / 31 / 92$

09/30/90

$10 / 13 / 92$

$02 / 01 / 92$

$06 / 30 / 92$

09/30/91

$10 / 31 / 92$

$01 / 15 / 93$

$10 / 15 / 89$

08/01/90

$10 / 1 / 90$

$01 / 01 / 91$

$05 / 01 / 91$

$01 / 15 / 93$

$10 / 15 / 89$

$08 / 15 / 90$

$11 / 30 / 92$

$01 / 15 / 93$

$03 / 01 / 93$

$07 / 01 / 93$

$03 / 01 / 93$

07/01/93

$08 / 31 / 94$

03/01/95
07/31/92

$11 / 13 / 92$

$01 / 15 / 93$

$10 / 15 / 89$

$08 / 01 / 90$

$10 / 01 / 90$

$02 / 15 / 91$

$08 / 15 / 92$

$11 / 13 / 92$

$01 / 15 / 93$

$10 / 15 / 89$

08/01/90

$10 / 01 / 90$

$02 / 15 / 91$

$10 / 15 / 91$

$10 / 15 / 89$

$09 / 15 / 90$

$11 / 30 / 92$

$01 / 15 / 93$

Task 4, No. 1

Task 5, No. 1

Phase IV

Task 2, No. 1

Task 3, No. 1 
where a regulated amount of sodium sulfite $\left(\mathrm{Na}_{2} \mathrm{SO}_{3}\right)$ is added. This chemical, combined with the addition of low-pressure steam to the deaerator tank, reduces the residual oxygen level in the water to less than $0.005 \mathrm{ppm}$, thereby reducing metal corrosion.

The equipment and chemicals used in the above treatment steps are operated and maintained by Office of Physical Plant (OPP) power plant operating personnel. However, the results of the daily boiler water analysis (which is conducted by EFRC personnel and is described later) is helpful in assuring proper operation of these steps and is provided to OPP power plant personnel on a regular basis.

Feedwater is drawn from the deaerator tank and fed to the boiler by the feedwater pump (Halberg Water Pump Model 2508 B 511.OB) which has a capacity of 40 gallons per minute and is located at the rear of the boiler. Two additional chemicals, NB-11 (a blend of phosphates and polymeric dispersing agents) and NB-64 (organic dispersant-descalent), are added from a small polyethylene tank located next to the feedwater pump. This equipment is shown in Figure 7. EFRC personnel are responsible for filling this tank when required. This is done by the following steps.

\section{Procedure for Filling the Chemical Tank}

NOTE THAT SAFETY GOGGLES AND RUBBER GLOVES MUST BE WORN WHEN FILLING THE CHEMICAL TANK

1. Add 6 liters of NB-64 to the chemical feed tank. (Quantity is subject to change based on the results of the boiler water analysis described below)

2. Add 3 liters of NB-11 to the chemical feed tank. (Quantity is subject to change based on the results of the boiler water analysis described below)

3. Fill the tank up to the 25 gallon level with softened water from the faucet located immediately to the left of the tank. DO NOT USE TAP WATER FROM THE LOWER CHROME PLATED FAUCET NEXT TO THE FEEDWATER PUMP.

6. Turn on circuit breaker 10 located in the electrical box on the wall next to the chemical tank.

5. Turn on the mixer for approximately 5 minutes.

6. Verify the stoke setting of the chemical feed pump. (present setting-3)

The chemical feed tank level should not be allowed to drop below the take-off port at the tank bottom. If this occurs, air will enter the chemical feed pump requiring repriming of the pump. This is done by one of the following procedures.

\section{Chemical Pump Priming - Procedure 1}

1. With the valve at the bottom of the chemical tank (V2) closed (see Figure 7), compress the hose between the tank and pump several times noting the release of any air 


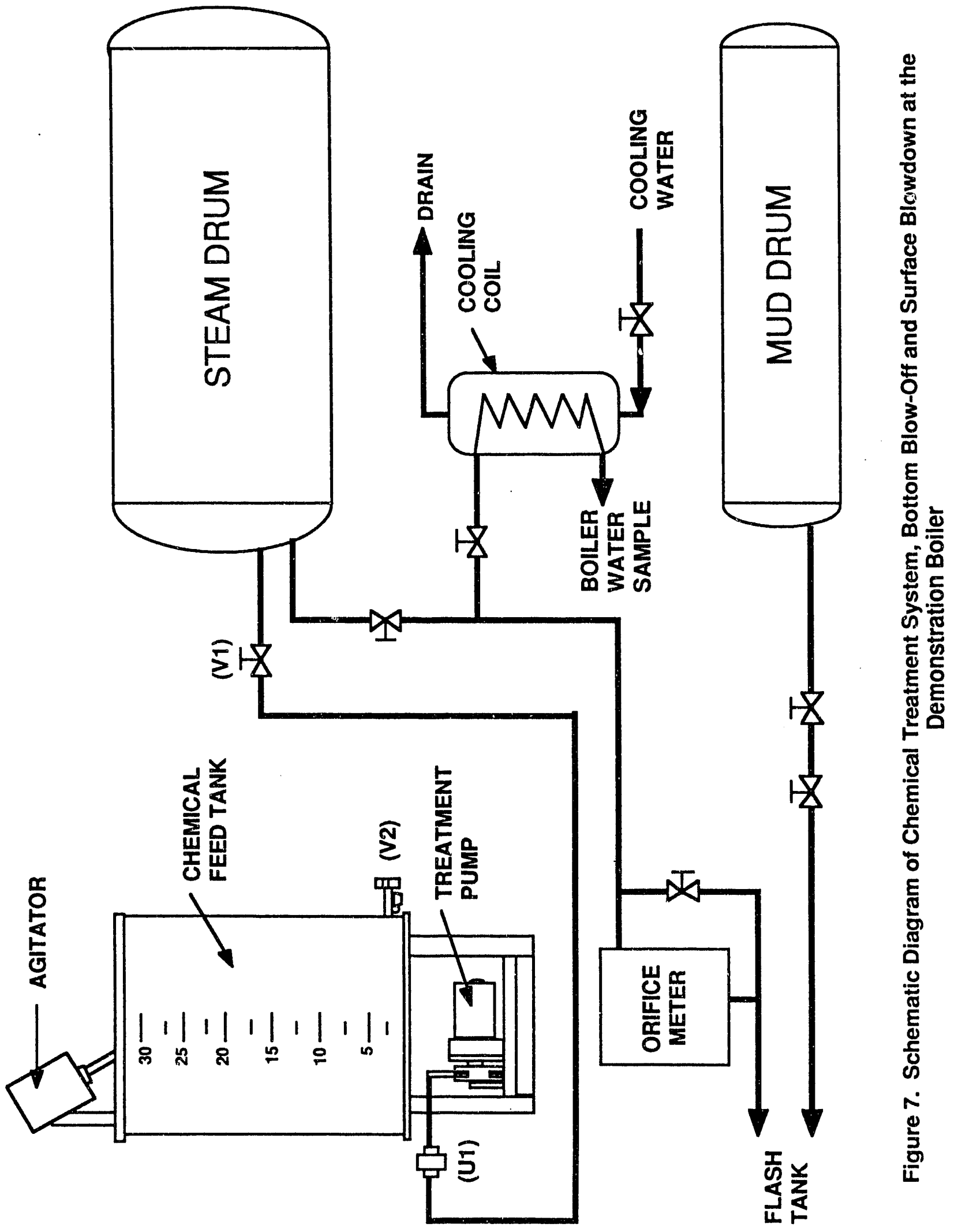


trapped inside the pump. Repeat until air is no longer released or until the pump begins to draw fluid down the hose. Slight tapping on the strainer and piping entering the pump may help in displacing the air. When the pump has been primed, open valve V2. (If Procedure 1 is not successful, then Procedure 2 should be used)

\section{Chemical Pump Priming - Procedure 2}

1. Close the valve on the chemical feed line at the entrance to the steam drum (V1) and the valve at the bottom of the chemical tank (V2).

2. Open the union located just beyond the outlet of the chemical feed pump (U1).

3. Open the valve at the bottom of the chemical tank (V2) and allow the water treatment chemicals to flow through the union for 5-10 seconds. Then close valve V2.

4. Reconnect the union and open valve V1.

5. Turn on circuit breaker 10 and note if liquid is moving downward through the hose connecting the tank and pump. If not, repeat steps 1-5 again. If the pump is working, open $\mathrm{V} 2$ and continue with normal operation.

A pump setting of 3 will require refilling of the chemical tank approximately every 8 hours. The effect of changes in the pump setting on chemical feed rate is:

- Stroke Setting $1-1.0 \mathrm{gal} / \mathrm{m}$

- Stroke Setting $2-2.1 \mathrm{gal} / \mathrm{m}$

- Stroke Setting $3-3.1 \mathrm{gal} / \mathrm{m}$

- Stroke Setting $4-4.1 \mathrm{gal} / \mathrm{m}$

- Stroke Setting $5-5.2 \mathrm{gal} / \mathrm{m}$

- Stroke Setting 6- $6.2 \mathrm{gal} / \mathrm{m}$

\section{Monitoring Boiler Water}

Monitoring the various water streams is an important part in the successful operation of steam boiler systems. The testing performed not only insures that a sufficient amount of treatment is given to the incoming water, but also that the desired levels of chemicals are maintained in the boiler.

To evaluate the success of the water treatment measures, two samples are collected on a daily basis. The first of these is a feedwater sample collected from the drip pan at the outlet of the feedwater pump. This sample is analyzed for total dissolved solids (conductivity), buffered and unbuffered, and for total hardness. This test is used to monitor the operation of the two water softeners. When operating properly, the softeners will maintain the total hardness in the feedwater to less than $1 \mathrm{ppm}$. The total hardness will begin to rise as the end of the useful softening cycle is reached. The two softeners are automatically regenerated after they have treated 150,000 and 185,000 gallons of water, respectively. To further ensure a correct fre- 
quency of regeneration, the total hardness in the exit stream is continuously monitored and an alarm triggered when a level of 3-4 ppm is detected.

A second sample collected from the boiler steam drum is run through a cooling coil before being analyzed. This sample is tested for soluble phosphate, sulfite, alkalinity, conductivity, and total hardness. The test procedures are:

\section{SULFITE:}

1. Measure a $50 \mathrm{ml}$. sample of boiler water into a casserole.

2. Add 2 sccops of Starch Acid Indicator (Code 552). DO NOT MIX VIGOROUSLY.

3. Titrate with $\mathrm{N} / 126$ Potassium Iodide/Iodate (Code 533). $\mathrm{ppm} \mathrm{SO}_{3}=\mathrm{mls} . \mathrm{N} / 126$ Potassium Iodide/Iodate $\mathrm{x} 10$ as $\mathrm{SO}_{3}$

\section{ALKALINITY:}

1. Measure a $25 \mathrm{ml}$. sample of boiler water into a casserole.

2. Add 4 drops of Phenolphthalein Indicator (Code 535).

3. Titrate with $\mathrm{N} / 50$ Sulfuric Acid until clear. Kecord the number of mls.

4. Add 4 drops of Methyl Purple Indicator (Code 529).

5. Continue titrating with N/50 Sulfuric Acid to a purple endpoint. Record the total number of mls. of acid.

$$
\begin{gathered}
\text { ppm P alkalinity }=\text { mls. of acid to } \mathrm{P} \text { endpoint } \mathrm{x} 40 \\
\text { ppm M alkalinity }=\text { total mls. of acid } \mathrm{x} 40 \\
\text { ppm } \mathrm{OH} \text { alkalinity }=2 \mathrm{P}-\mathrm{M} \\
\text { (all reported as } \mathrm{CaCO}_{3} \text { ) }
\end{gathered}
$$

\section{TOTAL HARDNESS:}

1. Measure $50 \mathrm{mls}$. of feedwater or boiler water into a casserole.

2. Add 13 of drops Hardness Buffer (Code 516).

3. Add 1 scoop of Hardness Indicator (Code 519).

4. Titrate to an EGG SHELL BLUE endpoint with Hardness Reagent (Code 521).

$$
\text { ppm total hardness }=\text { mls. Hardness Reagent } \times 20
$$

(reported as $\mathrm{CaCO}_{3}$ )

\section{CONDUCTIVITY (BUFFERED):}

1. Fill the casserole $3 / 4$ full with feedwater or boiler water.

2. Add 3 drops of Phenolphthalein Indicator (Code 535) and stir.

3. Add N/50 Sulfuric Acid until clear.

4. Verify the calibration of the DS meter by the internal standard.

5. Rinse the cell cup three times with the sample to be tested and then fill to at least $1 / 4$ " above the top electrode. Measure the conductivity. 


$$
\begin{aligned}
& \text { C V V D } \\
& \text { f.". } 1 \text { 1 livis }
\end{aligned}
$$

PHOSPHATE:

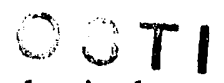

1. Rinse a color viewing tube with demineralized water. Rinse the plastic dropper several times with boiler water. Turbid samples should be filtered to obtain accurate results.

2. Fill the dropper to the $0.5-\mathrm{ml}$ mark with boiler water. Discharge t.le contents of the dropper into the color viewing tube.

3. Add demineralized water to the 5-ml mark on the viewing tube. Swirl the tube to mix.

4. Add the contents of one PhosVer 3 Phosphate Reagent Powder Pillow. Swirl to mix. Allow at least one minute, but no longer than five minutes, for color development. If phosphate is present, a blue-violet color will develop.

5. Insert the tube of prepared sample into the right top opening of the comparator and the second viewing tube filled with demineralized water into the left top opening.

6. Hold the comparator up to a light source and view through the two openings in front. Rotate the disc to obtain a color match. Read the $\mathrm{mg} / \mathrm{l}$ phosphate through the scale window.

A third sample from the water softener is collected and tested for total hardness only if the feedwater contains a hardness level of greater than 3-4 ppm. This test serves to verify that regeneration of the softeners is required.

The results from the analysis of these samples along with other important operating parameters are recorded in the daily boiler water log shown in Table 2. Also listed in the table are the desired ranges for the results of each analysis performed. Using these test results, appropriate action must be taken such as changing the quantity of treatment chemicals delivered to the boiler.

Steam Quality: Since it is impossible to completely separate all the water from the steam, some carryover will occur in any boiler. A throttling steam calorimeter has been installed in the steam header to measure the quality of the steam produced. The calorimeter is operated for several hours during steady state periods of the testing and the results used to determine the amount of carryover and the changes in blowdown required.

Bottom Blow-off and Surface Blowdown: The bottom blow-off and surface blowdown systems on the demonstration boiler are shown in Figure 7. The bottom blow-off consists of piping from the mud drum through two manually operated valves to either a drain or a flash tank in the East Campus Steam Plant. This part of the system is operated intermittently to remove accumulated sediment, such as sludge and accumulated matter, which has settled to the bottom of the boiler.

The surface blowdown consists of piping from the steam drum through a manually operated valve to an orifice meter and then to the East Campus Steam Plant flash tank. The 

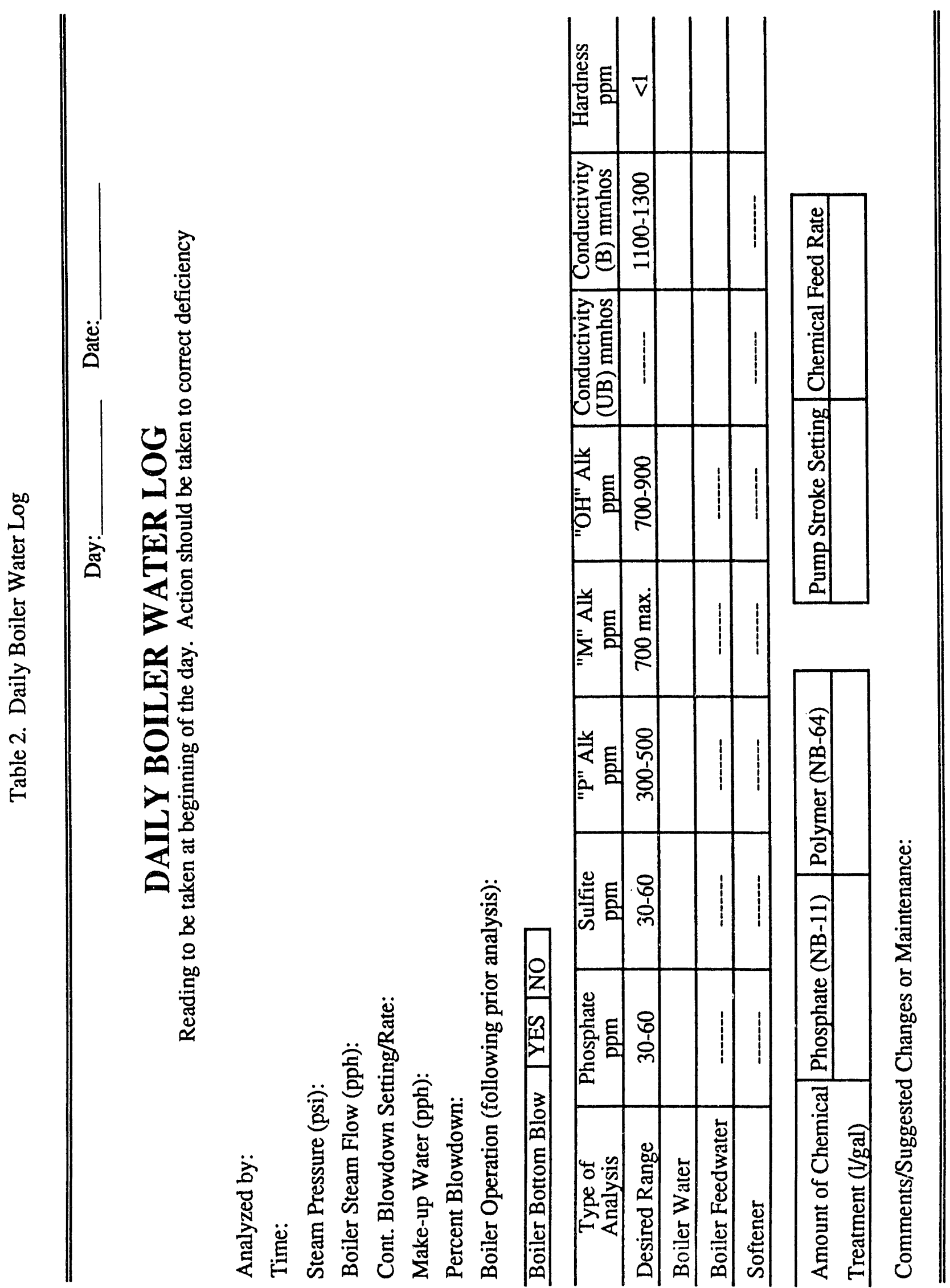
setting of the orifice meter, and thus the flow rate, is manually changed by EFRC personnel. This system is operated continuously to control the concentration of suspended or dissolved solids in the boiler water.

\subsubsection{Emissions Monitoring}

\section{System Overview}

A critical component in evaluating the overall combustion performance is the flue gas composition. Consequently, an emissions monitoring system (EMS) has been assembled and installed in the instrumentation trailer. The system, shown schematically in Figure 8, consists of sample withdrawal (sample probe), conditioning, and analysis (analyzer cabinet) subsystems.

\section{Sampling Probes}

The sampling probes (SF-1 and SF-2) consist of two 1" diameter by 10" long sintered metal filters inserted into the centerline of the duct exiting the boiler. The filters, made with Hastelloy X, have a porosity of $20 \mu \mathrm{m}$. Attached to each probe is a metal shield to prevent direct particle inpingement. The probe assembly is supported in the duct by a short length of $1 / 2$ " diameter stainless steel tube extending through a flange mounted on the duct wall. Using a three-way valve, a sample can be withdrawn through either probe (SF-2 is located approximately one foot below SF-1). If one filter becomes clogged with particulates, the other filter is used to allow continuous sampling until the plugged filter can be cleaned with a backflush of high pressure air. An additional three-way valve has been installed in the sample conditioning section of the system to permit the backflushing.

\section{Sample Conditioning}

After the gas sample is withdrawn from the duct, it is conditioned before being analyzed. The first step in the conditioning process is the removal of water which interferes with the infrared measurements of sulfur dioxide. The gas sample is passed through a single coil refrigeration bath $(\mathrm{RC})$ where the gas temperature is lowered to $35-40^{\circ} \mathrm{F}$. At this temperature much of the water vapor is condensed and separated from the sample. Approximately 0.8 to $1.0 \mathrm{wt} . \%$ water remains in the gas stream. The water, which is collected from the bottom of the bath in a ten foot length of tygon tubing, must be drained by EFRC personnel every 3 to 4 hours. Future improvements are planned to eliminate the need for manual draining of this line.

To further dry the gas sample, a pair of membrane type dryers (PPD-1 and PPD-2) has been installed in series. These dryers utilize a hygroscopic ion-exchange membrane to selectively remove water vapor from the gas stream. The membrane is expendable desiccant in tubular form. The dryers are fabricated in a shell-and-tube configuration with the wet gas flowing through the tubes and the water vapor molecules are transferred through the walls of the 


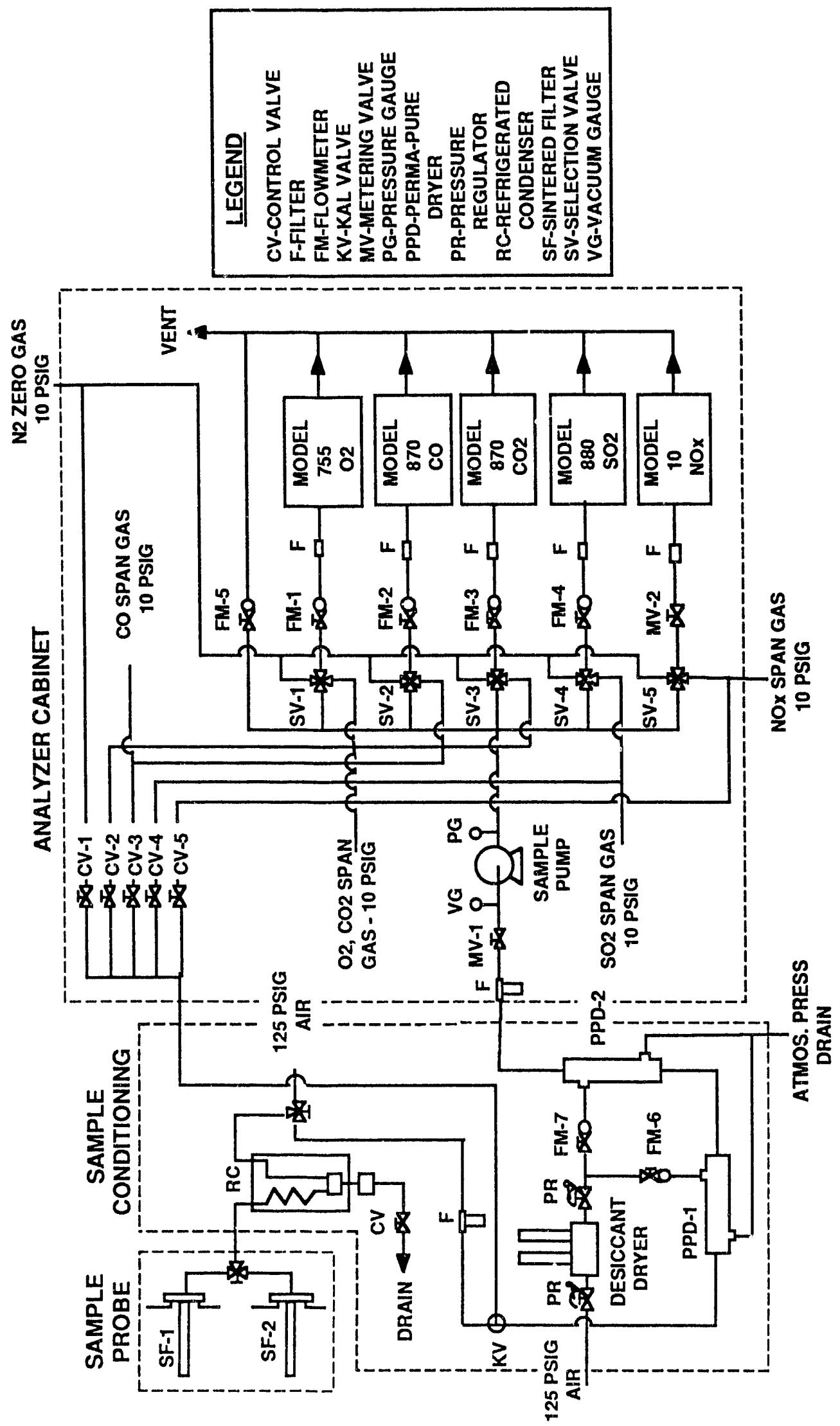

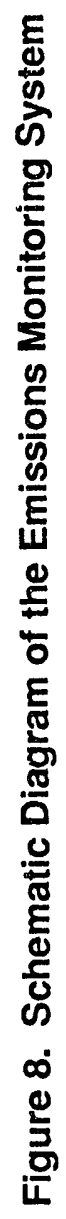


tubing. A supply of dry air at a flow rate of approximately three times that of the sample (3.0 and $1.0 \mathrm{SCFH}$, respectively) is fed countercurrent to the gas sample on the shell side of the dryers. The dry air is generated by passing house air through a desiccant dryer.

Particulates are removed using a 2.25 inch diameter by 4 inch in length polypropylene filter with a pore size of 1 micron. This filter is located between the two stages of drying. If particulates are not removed, they can plug tie sample lines and instrumentation and cause inconsistent readings. Additional in-line sintered stainless steel filters with an effective element area of 0.55 square inches are used prior to the gas analyzers to ensure that the sample is clean.

\section{Analyzers}

The majority of the EMS system is housed within the instrumentation cabinets in the trailer. This includes analyzers, pumps, flowmeters, and valves. The following analyzers are contained in the EMS system:

\section{Analyzer}

1. Model 755 Paramagnetic Oxygen Analyzer

2. Model 870 NDIR Carbon Monoxide Analyzer

3. Model 870 NDIR Carbon Dioxide Analyzer

4. Model 880 NDIR Sulfur Dioxide Analyzer

5. Model 10 Chemiluminescent $\mathrm{NO}-\mathrm{NO}_{\mathrm{x}}$ Analyzer

\section{Manufacturer}

Rosemount Analytical Inc. Rosemount Analytical Inc. Rosemount Analytical Inc. Rosemount Analytical Inc. Thermo Environmental Inst. Inc.

After the gas sample is drawn through the sample probe and conditioning systems, it is delivered to the analyzers by the sample pump at a rate of approximately 0.85 SCFM. A metering valve (MV-1) prior to the pump is used to control the total flow rate of the gas sample. Two gauges monitor the pressures before and after the pump. The pump delivers the sample to each of the above analyzers through a 5-way selector valve (SV-1 to SV-5), flowmeter (FM-1 to FM$4)$, and a final filter. A second metering valve (MV-2) is used to control the flow rate through the $\mathrm{NO}_{\mathrm{x}}$ analyzer. The excess sample is measured by a separate flowmeter (FM-5), recombined with the sample that has passed through the analyzers, and vented to the atmosphere.

The selector valves allow each analyzer to be taken off-line and their calibration checked. This is done by introducing zero (i.e., nitrogen) or span (certified calibration) gas using the appropriate selector valve. However, the primary method of calibration is performed by delivering the zero and span gases through a manifold of control valves (CV-1 to CV-5) to a Kal Valve (KV) located near the sampling point.

\section{Startup and Calibration Procedures}

The following instructions constitute a condensed procedure which is followed for startup of the EMS. The calibration procedures specified in steps 10-18 below are completed every eight hours during continuous operation. 
1. Turn on the refrigerated condenser, Perma Pure dryers, and desiccant dryer and allow them to reach operating conditions before proceeding. The operating conditions are:

$$
\begin{aligned}
& \text { Refrigerated Condenser } \\
& \text { Operating temp. - } 35^{\circ} \mathrm{F} \\
& \text { Desiccant Dryer } \\
& \text { Inlet air pressure - } 80 \mathrm{psig} \\
& \text { Outlet air pressure - } 40 \mathrm{psig} \\
& \text { Perma Pure Dryers } \\
& \text { Air flow rate - } 3.0 \mathrm{SCFH}
\end{aligned}
$$

The condensate from the refrigerated condenser should be drained through the tygon line located under the unit.

2. Turn on the terminal strips located inside each cabinet. This will supply power to the analyzers, roughing pump and by-pass pump. The additional switch, which supplies power to the sample pump, should not be turned on at this time.

3. Open all calibration gas cylinders located to the right of the analyzer bank.

NOTE: Sample pressure should not exceed 10 psig. Analyzer damage can occur at higher pressures.

4. Turn on the ozone power for the $\mathrm{NO}_{\mathrm{x}}$ analyzer. Open the bottom drawer of the $\mathrm{NO}_{\mathrm{x}}$ analyzer and check the oxygen pressure gauge for 2 psig. If incorrect, adjust the oxygen regulator.

5. Open the valve on the vent flowmeter (FM-5).

6. Turn on the sample pump switch and observe the vacuum gauge. This should read $>20$ inches of $\mathrm{Hg}$. If it does not, the system should be checked for leaks.

7. Open the metering valve (MV-1) and allow sample to be pulled through the system for approximately half an hour with the boiler on line. This allows the moisture level in the Perma Pure Dryers to reach a constant value.

8. Turn the 5 selector valves (SV-1 to SV-5) to sample.

9. Adjust the flow rates on the flowmeters (FM-1 to FM-4) as follows:

\begin{tabular}{ccc} 
Analyzer & Flow rate & Flowmeter reading \\
\hline $\mathrm{O}_{2}$ & $250 \mathrm{cc} / \mathrm{min}$ & 35 \\
$\mathrm{CO}$ & $750 \mathrm{cc} / \mathrm{min}$ & 45 \\
$\mathrm{CO}_{2}$ & $750 \mathrm{cc} / \mathrm{min}$ & 45 \\
$\mathrm{SO}_{2}$ & $750 \mathrm{cc} / \mathrm{min}$ & 45 \\
$\mathrm{NO}_{\mathrm{x}}$ & $2 \mathrm{SCFH}$ & 2
\end{tabular}


The flowmeter for the $\mathrm{NO}_{\mathrm{x}}$ analyzer is on the front panel of the analyzer and a metering valve (MV-2) is used to control tiis flow rate. If the above flow rates cannot be achieved, the vent flow can be restricted to bring the flows into acceptable limits. The sample pressure gauge should read approximately 5 psig after this step.

10. The $\mathrm{O}_{2}$ analyzer is zeroed by positioning SV-1 to zero and adjusting the flow rate. When a stable reading is achieved, adjust the potentiometer labeled zero until the meter has stabilized at zero. Then return SV-1 to the sample position.

11. Close the 3-way valve located between the sampling probes.

12. Open the nitrogen control valve $(\mathrm{CV}-1)$ and then slowly open the calibration gas flowmeter until the flow to each analyzer is restored.

13. Allow nitrogen to pass through the analyzers for at least 2 minutes or until the meter reading has sufficiently stabilized. If a zero reading is not achieved on the $\mathrm{O}_{2}$ analyzer, the system should be checked for leaks.

14. Adjust the potentiometers labeled zero or background suppression, until the meter has stabilized at zero. The $\mathrm{SO}_{2}$ analyzer zero setting is done by pressing zero then enter. Using the up and down arrow keys, adjust the percent of the zero potentiometer used to the lowest positive setting possible, then press enter. The nitrogen calibration gas is hydrated to a level consistent with the sample gas drawn through the line. The moisture now present in the gas allows for compensation of the interference by water vapor on the $\mathrm{SO}_{2}$ reading.

15. Close the nitrogen control valve, open the $\mathrm{SO}_{2}$ control valve (CV-4) and, if necessary, adjust the calibration gas flowmeter until the desired $\mathrm{SO}_{2}$ flow rate is achieved.

16. The $\mathrm{SO}_{2}$ analyzer span setting is done by pressing span then enter. Using the up and down arrow keys, adjust the percent of the span potentiometer used until the measured value is approximately $100 \mathrm{ppm}$ below the span gas value, then press enter.

17. Continue in the same manner for each of the remaining analyzers using their respective span gas.

18. Close all calibration control valves and the calibration gas flowmeter (FM-5). Open the 3-way valve to one of the sampling probes and adjust the vent flowmeter if necessary.

Note that each analyzer, with the exception of the $\mathrm{SO}_{2}$ analyzer, can be dropped off-line and calibrated individually. The first part of this procedure is outlined in step 10 above. Similarly, span gas could be introduced to the analyzer by positioning the selector valves. However, 
the primary method of calibration is performed by delivering the zero and span gas to the Kalvalve near the sampling location.

During continuous operation the following items should be monitored on a regular basis:

1. Condensate level in the drain line from the refrigerated condenser. (This should be emptied every 2-3 hours for normal operation) NOTE: The sample pump must be turned off before draining the line.

2. The following system pressures and flow rates:

(a) inlet and outlet air pressure for the desiccant dryer,

(b) flow rate to each analyzer,

(c) vent flow rate,

(d) system vacuum and pressure

(e) flow rate to each Perma Pure Dryer

\subsection{PHASE II: CONSTRUCTION AND START UP}

In Phase II, Tasks 1, 3, and 4 have been completed. Work continued on Task 2, SCCWS Preparation, and the results are discussed below. A schematic of the demonstration boiler system is shown in Figure 9.

\subsection{Task 2. SCCWS Preparation}

This section summarizes the activities to clean and prepare SCCWS during this reporting period. Details of the coal company, coal cleaning facility, and SCCWS preparation have been reported previously [7].

\section{Preparation of Clean Coal}

Approximately 283 tons of Brookville seam coal were transported from Perry Brothers Coal Company to the Reddinger Coal Company coal cleaning facility. The clean coal contained 4.0 and 0.7 wt. \% (dry basis) ash and sulfur, respectively. The heating value of the coal was $14,243 \mathrm{Btu} / \mathrm{lb}$ (dry basis).

\section{Slurry Procurement}

Approximately 11.5 tons of SCCWS were prepared by Kennedy Van Saun (KVS) and transported to Penn State. Tables 3 to 6 summarize the KVS quality assurance production records and summarize the solids loading, particle size distribution, viscosity, $\mathrm{pH}$, coal feed rates, and additive dosages. The SCCWS was transported from KVS via 5,600 gallon single compartment stainless steel tankers. Tankers were unloaded immediately upon arrival. Sedimentation in the tankers was soft and was easily rinsed out. Six tankers of SCCWS were received.

The solids loading of the SCCWS prepared at KVS was approximately 65-67 wt. \%. The SCCWS was diluted to 60-62 wt. \% prior to combustion testing in order to reduce its viscosity and improve atomization. 


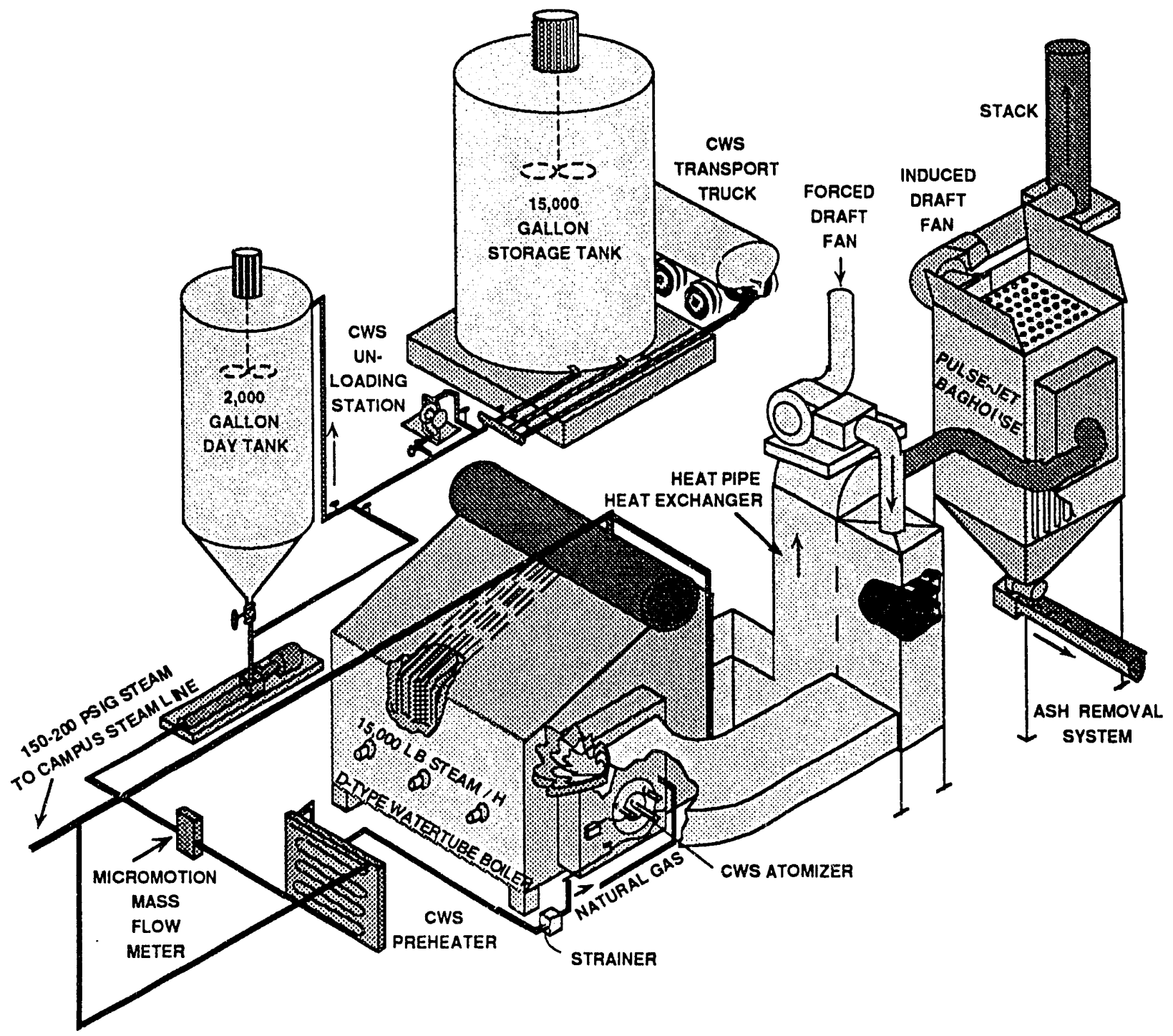

Figure 9. Penn State's SCCWS-Fired Boiler System 
ปू

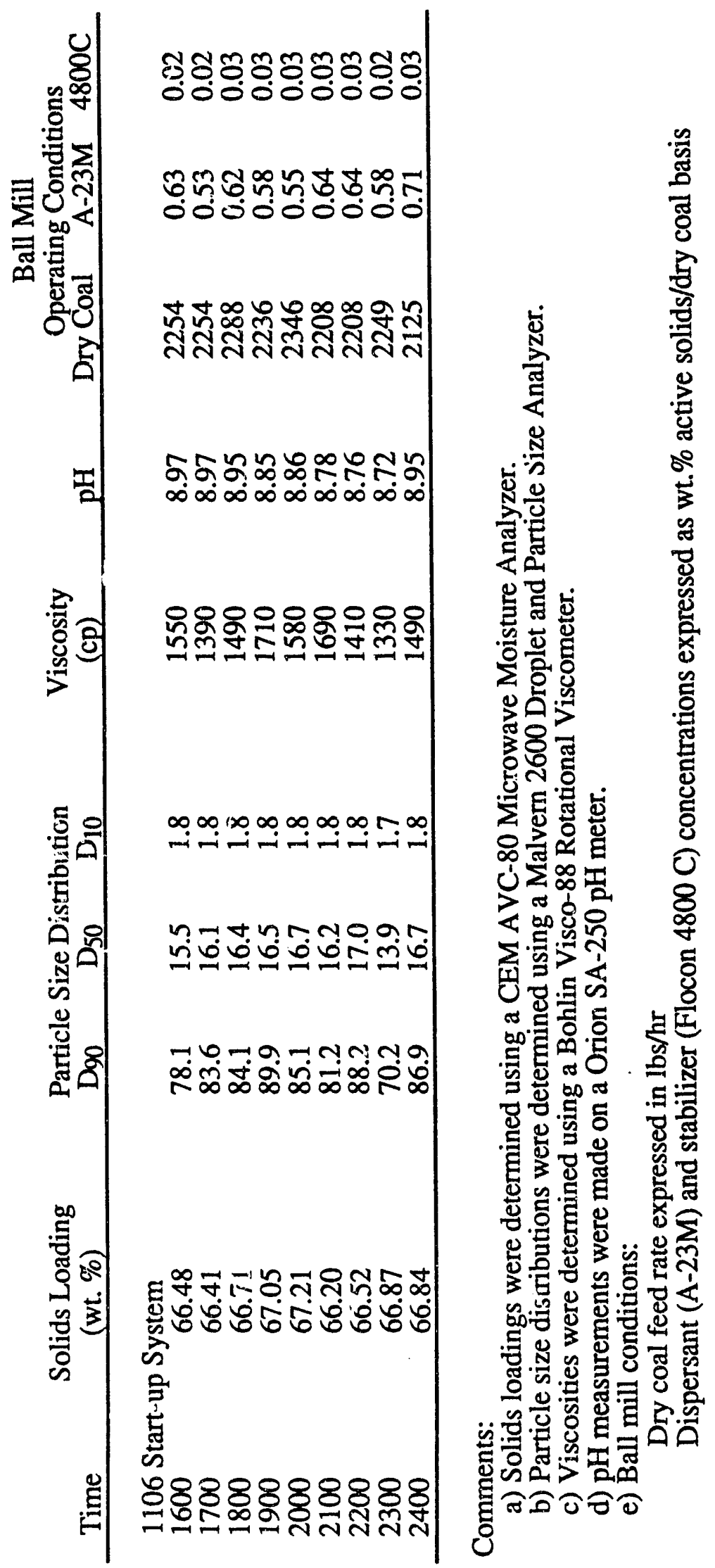




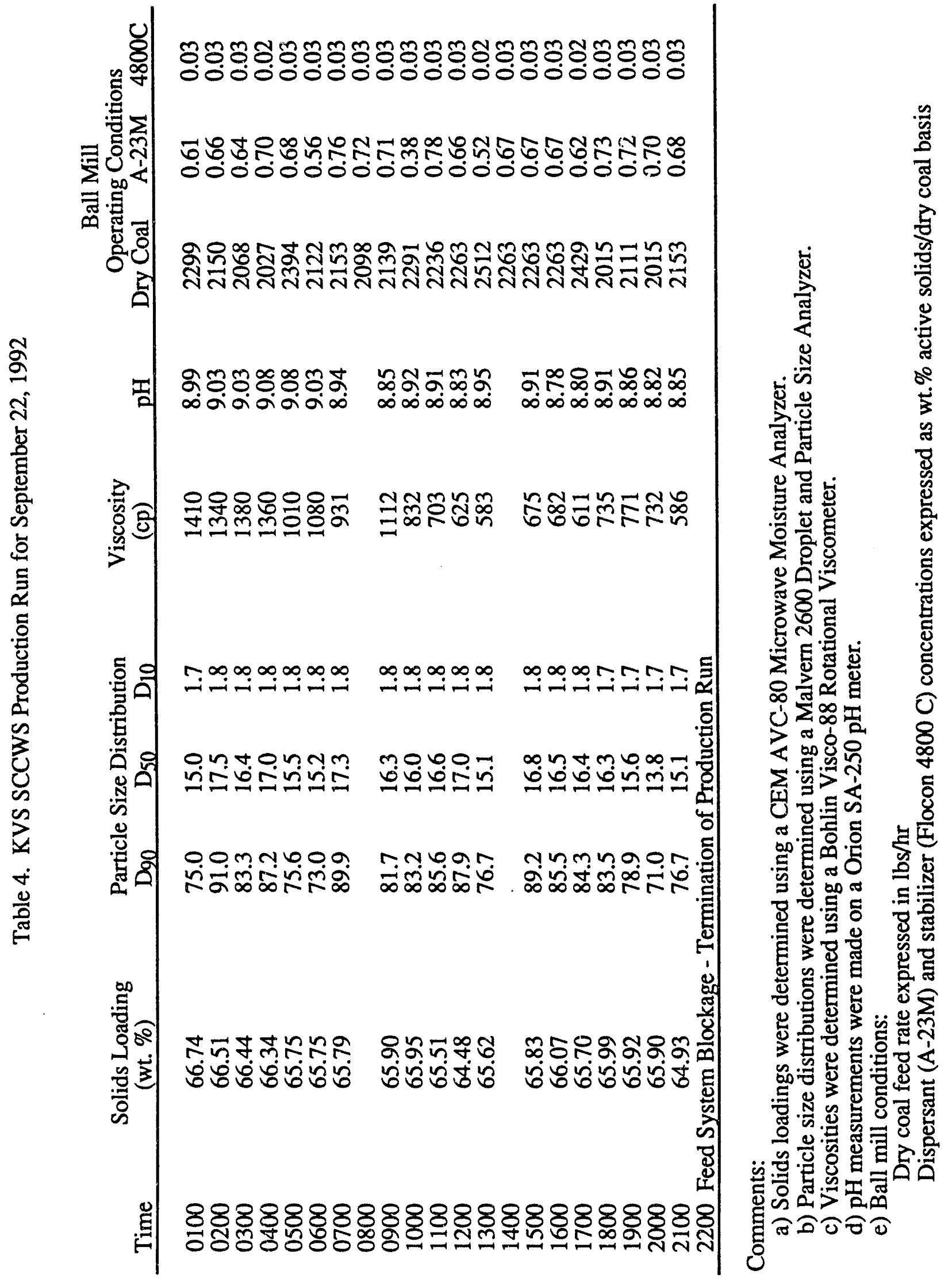


合

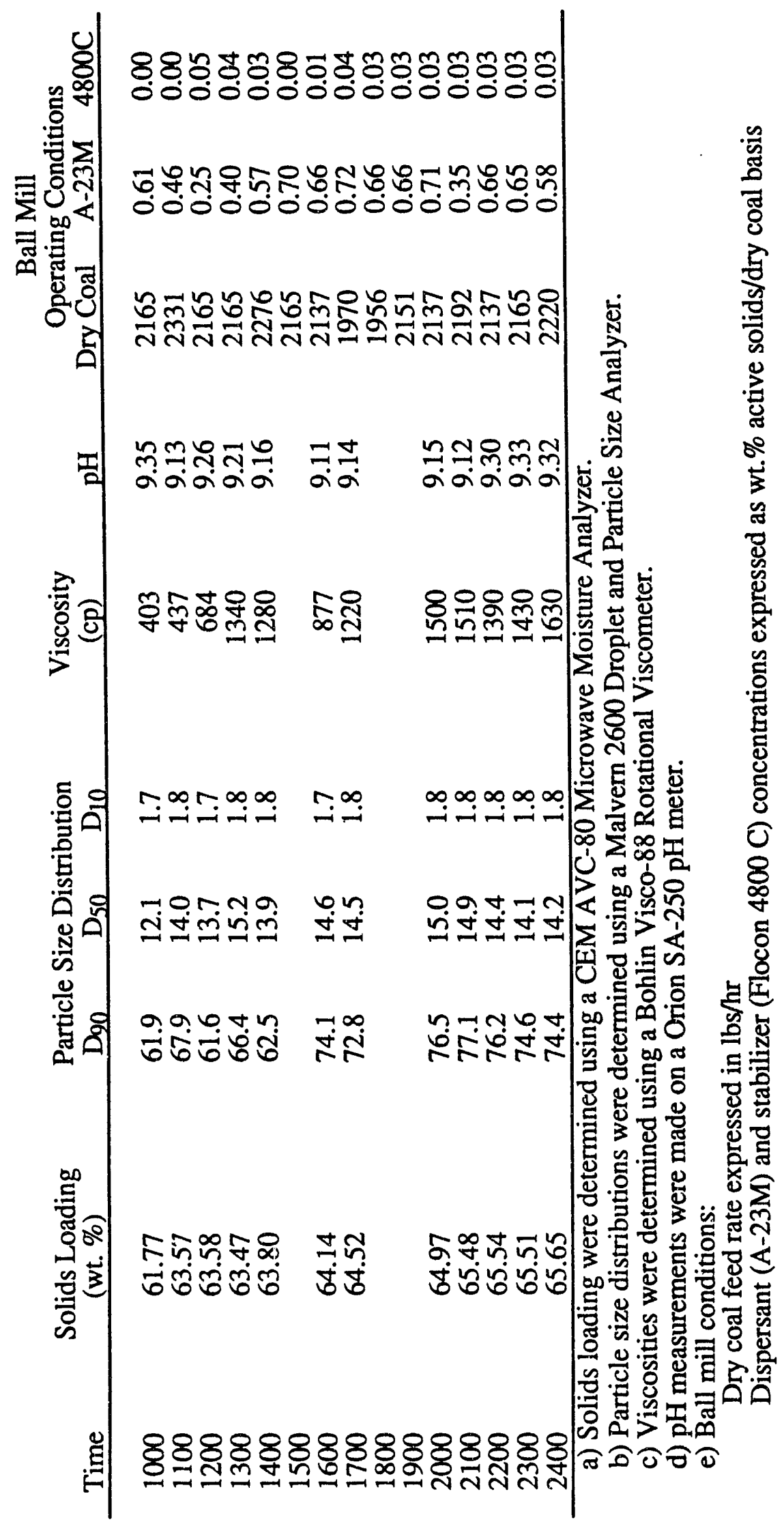




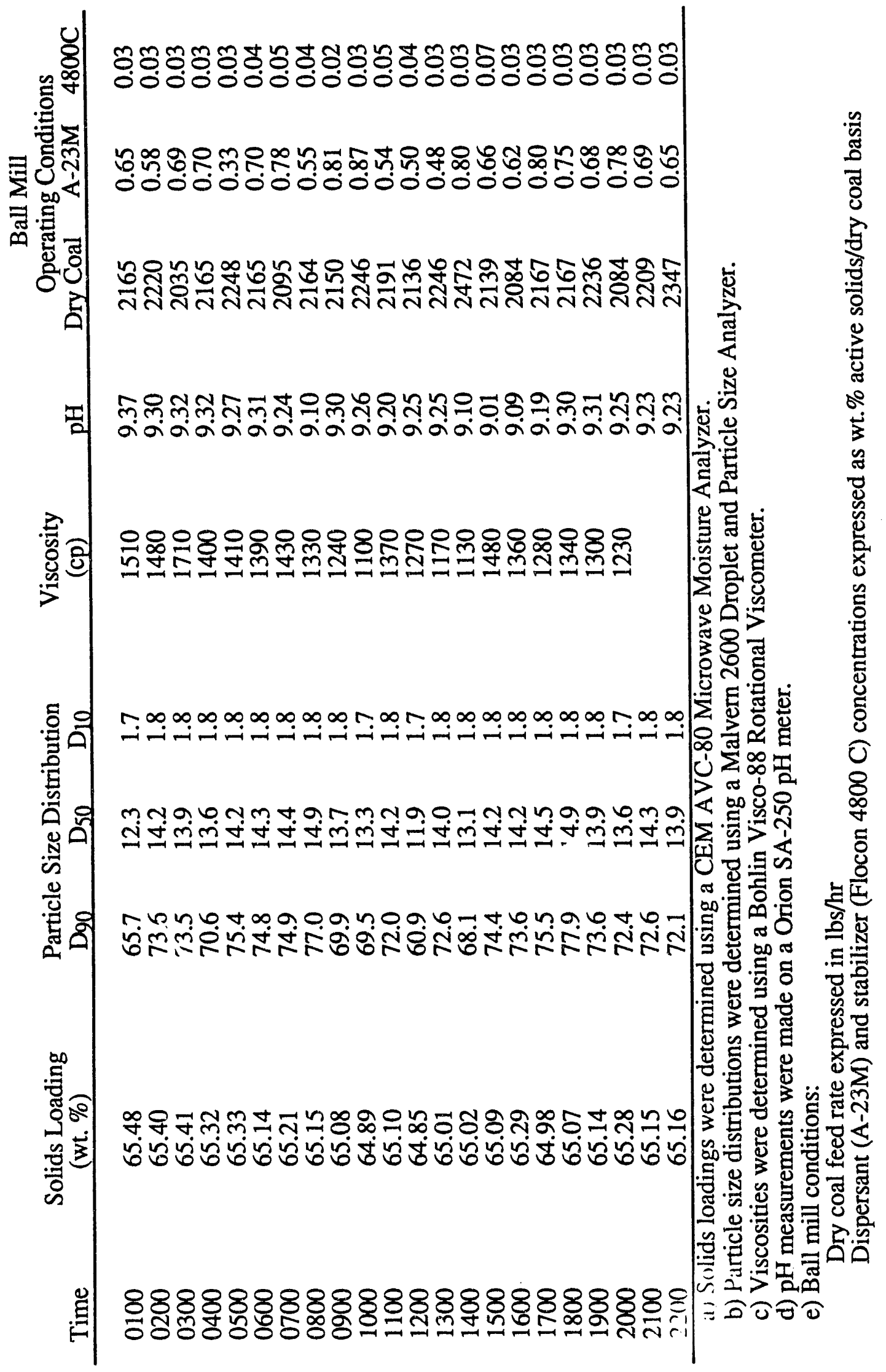




\subsection{PHASE III: DEMONSTRATION AND EVALUATION}

\subsection{Task 1. Test Burn}

\subsubsection{Subtask 1a. SCCWS Combustion Performance}

Approximately 474 hours of testing were accumulated during the first demonstration, of which 132 hours were accumulated this reporting period. A summary of the testing performed during this reporting period is presented in the following subsections. Testing through August 1992 was summarized in previous semiannual reports $[5,6]$.

\section{September 1992}

Testing was conducted in September to evaluate the effect of atomization air pressure on combustion performance. A portable, diesel-fired air compressor was used to generate atomizing air pressures greater than $\sim 100$ psig. In addition, a quarl, which is shown in Figure 10, was installed in the boiler to enhance flame stability. The quarl was used during the remainder of the test program. Three tests were conducted for a total of approximately 17 hours for which detailed energy and mass balances were conducted. The results from the September testing are summarized in Table 7.

The boiler was fired at 18.5-19.5 million Btu/h with 31-32\% natural gas support and SCCWS preheat. The tests were conducted using the modified extra-high capacity (MXHC) plug and high capacity cap with a spray angle of $65^{\circ}\left(\mathrm{HC} 65^{\circ}\right)$. Details of the Faber atomizer, which was provided with the boiler, and plug and cap specifications are contained in the previous semiannual report [6]. Using atomizing air pressures of 106,148 , and $170 \mathrm{psig}$, the combustion efficiency was approximately 90,93 , and $94 \%$, respectively. Combustion efficiencies of $93-$ $94 \%$ are the highest values achieved to date. Because the Test 1 was conducted with a lower solids loading as well as lower atomizing air pressure, it is not clear from the September testing if the increase in combustion efficiency is due to the increase in solids loading, or the atomizing air pressure or the addition of the quarl. When comparing the results from Test 1 with results from previous testing, there is no direct evidence that the quarl improved combustion performance. Boiler efficiencies improved to $79-80 \%$ during the September testing, while the steam production rate was approximately $13,000-14,000 \mathrm{lb} / \mathrm{h}$.

\section{October 1992}

In October, $\sim 94$ hours firing SCCWS were accumulated. Table 8 summarizes the results from the October testing. The specific objectives of the tests were:

- Test 1 - Evaluate the effect of high atomizing air pressure (186 psig) using the $\mathrm{MXHC}$ and $\mathrm{HC} 65^{\circ}$ when firing SCCWS at a rate of $\sim 19$ million Btu/h and $31 \%$ natural gas support;

- Test 2-Repeatability check of Test 1 ;

- Test 3 - Evaluate the effect of high atomizing air pressure (186 psig) using the 


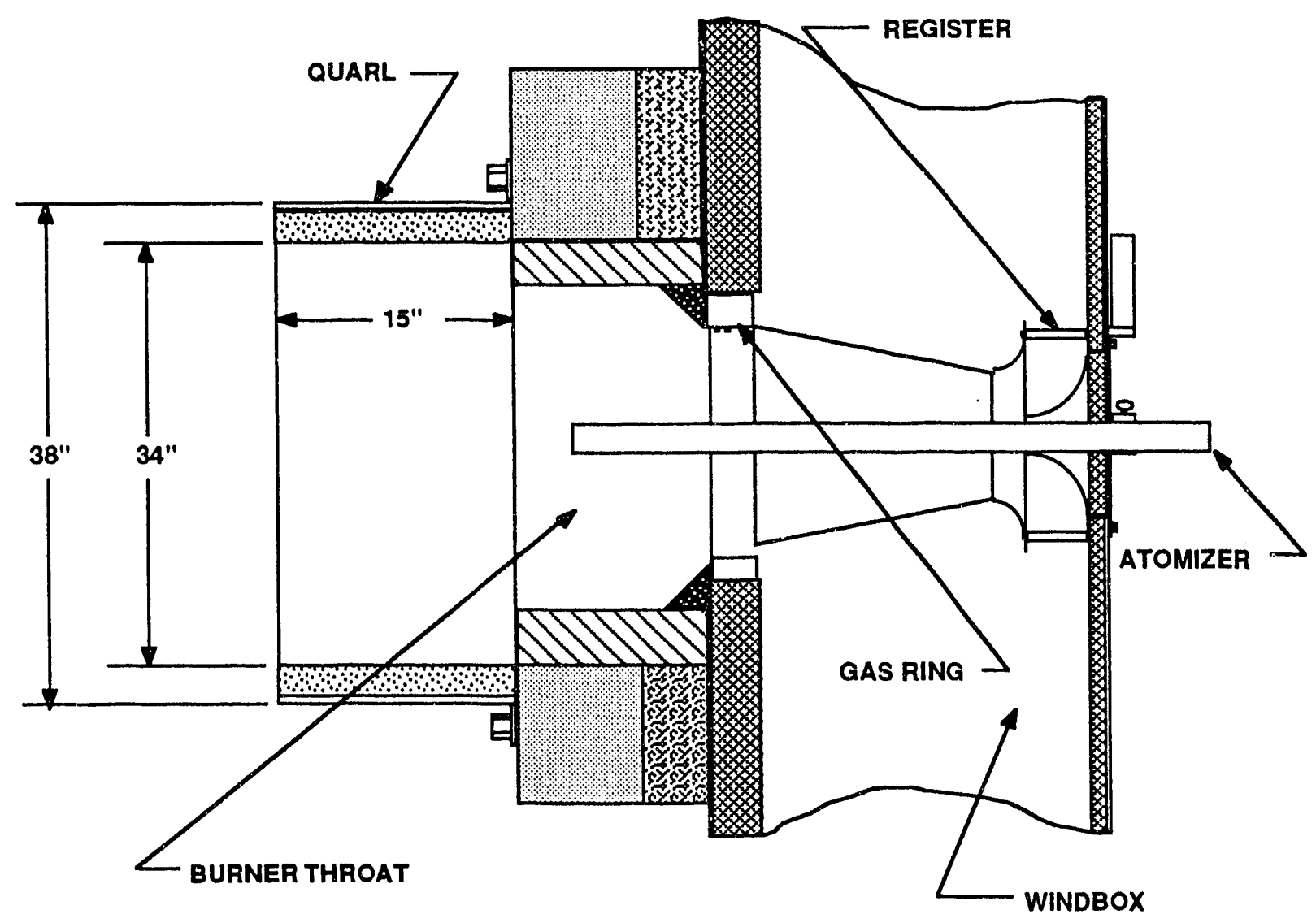

BURNER TILE
FIREBRICK
INSULATORY BRICK
INSULATION BOARD
PLASTIC REFRACTORY
HARD FACED REFRACTORY

Figure 10. Side View of the Quarl and Burner 
Table 7. Summary of September 1992 Testing $^{a}$

\begin{tabular}{|c|c|c|c|}
\hline Test Number & 1 & 2 & 3 \\
\hline Length of SCCWS Firing (hours) & 5.5 & 5.5 & 5.5 \\
\hline $\begin{array}{l}\text { Firing Rate }(\mathrm{MM} \text { Btu/h) } \\
\text { Natural Gas } \\
\text { SCCWS } \\
\text { Total }\end{array}$ & $\begin{array}{l}5.6 \\
13.1 \\
18.7\end{array}$ & $\begin{array}{r}5.9 \\
13.5 \\
19.4\end{array}$ & $\begin{array}{r}6.0 \\
13.5 \\
19.5\end{array}$ \\
\hline Gas Support (\%) & 31.9 & 30.5 & 30.6 \\
\hline $\begin{array}{l}\text { Air Preheater Temperatures }\left({ }^{\circ} \mathrm{F}\right) \\
\text { Combustion Air Inlet } \\
\text { Combustion Air Outlet } \\
\text { Flue Gas Inlet } \\
\text { Flue Gas Outlet }\end{array}$ & $\begin{array}{l}65 \\
352 \\
566 \\
345\end{array}$ & $\begin{array}{r}57 \\
352 \\
572 \\
349\end{array}$ & $\begin{array}{r}64 \\
365 \\
587 \\
358\end{array}$ \\
\hline Combustion Air Temperature $\left({ }^{\circ} \mathrm{F}\right)^{b}$ & 335 & 341 & 345 \\
\hline Steam Flow $(\mathrm{lb} / \mathrm{h})$ & 11,332 & 13,143 & 14,072 \\
\hline Boiler Efficiency (\%) & 76.9 & 79.3 & 79.5 \\
\hline $\begin{array}{l}\text { Combustion Efficiency }(\%)^{c} \\
\text { Total } \\
\text { Coal }\end{array}$ & $\begin{array}{l}92.9 \\
90.2\end{array}$ & $\begin{array}{l}94.9 \\
93.0\end{array}$ & $\begin{array}{l}95.2 \\
93.5\end{array}$ \\
\hline Atomizing Air Pressure (psig) & 106 & 148 & 170 \\
\hline SCCWS Temperature $\left({ }^{\circ} \mathrm{F}\right)$ & 148 & 139 & 137 \\
\hline SCCWS Solids Loading (wt. \%) & 57.8 & 60.1 & 60.6 \\
\hline $\begin{array}{l}\text { Baghouse } \\
\text { Inlet Temperature }\left({ }^{\circ} \mathrm{F}\right) \\
\text { Outlet Temperature }\left({ }^{\circ} \mathrm{F}\right)\end{array}$ & $\begin{array}{l}333 \\
308\end{array}$ & $\begin{array}{l}336 \\
312\end{array}$ & $\begin{array}{l}344 \\
318\end{array}$ \\
\hline $\begin{array}{l}\text { Flue Gas Composition (dry basis) } \\
\mathrm{O}_{2}(\%) \\
\mathrm{CO}(\mathrm{ppm}) \\
\mathrm{CO}_{2}(\%) \\
\mathrm{SO}_{2}(\mathrm{ppm} ; \mathrm{lb} / \mathrm{MM} \mathrm{Btu}) \\
\mathrm{NO}_{\mathrm{x}}(\mathrm{ppm} ; \mathrm{lb} / \mathrm{MM} \mathrm{Btu}) \\
\end{array}$ & $\begin{array}{c}3.7 \\
164 \\
13.5 \\
338 ; 0.64 \\
645 ; 0.88\end{array}$ & $\begin{array}{c}3.5 \\
151 \\
13.7 \\
415 ; 0.77 \\
761 ; 1.02\end{array}$ & $\begin{array}{c}3.2 \\
168 \\
13.9 \\
398 ; 0.73 \\
794 ; 1.05\end{array}$ \\
\hline
\end{tabular}

${ }^{a}$ The quarl, $\mathrm{MXHC}$ plug and $\mathrm{HC} 65^{\circ}$ cap were used for the September testing

${ }^{b}$ Measured at windbox, after in-duct auxiliary gas burner; in-duct burner was not operated during testing

${ }^{c}$ Total combustion efficiency includes contribution from natural gas 
Table 8. Summary of October 1992 Testing $^{a}$

\begin{tabular}{|c|c|c|c|c|c|c|}
\hline Test Number & 1 & 2 & 3 & 4 & 5 & 6 \\
\hline Length of SCCWS Firing (hours) & 5.5 & 6.5 & 8 & 9.5 & 5 & 4.5 \\
\hline $\begin{array}{l}\text { Firing Rate (MM Btu/h) } \\
\text { Natural Gas } \\
\text { SCCWS } \\
\text { Total }\end{array}$ & $\begin{array}{r}5.9 \\
13.3 \\
19.2\end{array}$ & $\begin{array}{r}6.0 \\
13.2 \\
19.2\end{array}$ & $\begin{array}{r}6.0 \\
13.3 \\
19.3\end{array}$ & $\begin{array}{r}5.9 \\
12.8 \\
18.7\end{array}$ & $\begin{array}{r}2.4 \\
17.0 \\
19.4\end{array}$ & $\begin{array}{r}6.0 \\
13.3 \\
19.3\end{array}$ \\
\hline Gas Support (\%) & 30.9 & 31.1 & 31.3 & 31.8 & 12.4 & 31.0 \\
\hline $\begin{array}{l}\text { Air Preheater Temperatures }\left({ }^{\circ} \mathrm{F}\right) \\
\text { Combustion Air Inlet } \\
\text { Combustion Air Outlet } \\
\text { Flue Gas Inlet } \\
\text { Flue Gas Outlet }\end{array}$ & $\begin{array}{r}69 \\
364 \\
585 \\
365\end{array}$ & $\begin{array}{r}78 \\
364 \\
575 \\
380\end{array}$ & $\begin{array}{r}68 \\
358 \\
580 \\
356\end{array}$ & $\begin{array}{l}69 \\
357 \\
572 \\
350\end{array}$ & $\begin{array}{l}73 \\
361 \\
570 \\
352\end{array}$ & $\begin{array}{r}80 \\
363 \\
567 \\
354\end{array}$ \\
\hline Combustion Air Temperature $\left({ }^{\circ} \mathrm{F}\right)^{b}$ & 350 & 348 & 342 & 339 & 339 & 344 \\
\hline Steam Flow $(\mathrm{lb} / \mathrm{h})$ & 13,794 & N.M. & N.M. & N.M. & N.M. & N.M. \\
\hline Boiler Efficiency (\%) & 79.2 & 79.2 & 78.8 & 78.9 & 78.0 & 79.0 \\
\hline $\begin{array}{l}\text { Combustion Efficiency }(\%)^{d} \\
\quad \text { Total } \\
\text { Coal }\end{array}$ & $\begin{array}{l}95.2 \\
93.5\end{array}$ & $\begin{array}{l}95.3 \\
93.5\end{array}$ & $\begin{array}{l}94.2 \\
92.1\end{array}$ & $\begin{array}{l}94.3 \\
92.1\end{array}$ & $\begin{array}{l}93.5 \\
92.4\end{array}$ & $\begin{array}{l}94.4 \\
92.3\end{array}$ \\
\hline Atomizing Air Pressure (psig) & 186 & 186 & 186 & 150 & 150 & 186 \\
\hline SCCWS Temperature $\left({ }^{\circ} \mathrm{F}\right)$ & 141 & 131 & 125 & 125 & 140 & 132 \\
\hline SCCWS Solids Loading (wt. \%) & 60.0 & 60.4 & 62.2 & 62.2 & 60.5 & 60.5 \\
\hline $\begin{array}{l}\text { Baghouse } \\
\quad \text { Inlet Temperature }\left({ }^{\circ} \mathrm{F}\right) \\
\text { Outlet Temperature }\left({ }^{\circ} \mathrm{F}\right)\end{array}$ & $\begin{array}{l}350 \\
324\end{array}$ & $\begin{array}{l}343 \\
318\end{array}$ & $\begin{array}{l}342 \\
313\end{array}$ & $\begin{array}{l}335 \\
308\end{array}$ & $\begin{array}{l}337 \\
308\end{array}$ & $\begin{array}{l}339 \\
307\end{array}$ \\
\hline $\begin{array}{l}\text { Flue Gas Composition (dry basis) } \\
\mathrm{O}_{2}(\%) \\
\mathrm{CO}(\mathrm{ppm}) \\
\mathrm{CO}_{2}(\%) \\
\mathrm{SO}_{2}(\mathrm{ppm} ; \mathrm{lb} / \mathrm{MM} \mathrm{Btu}) \\
\mathrm{NO}_{\mathrm{x}}(\mathrm{ppm} ; \mathrm{lb} / \mathrm{MM} \mathrm{Btu})\end{array}$ & $\begin{array}{c}3.2 \\
165 \\
13.6 \\
411 ; 0.75 \\
794 ; 1.05\end{array}$ & $\begin{array}{c}3.6 \\
175 \\
13.7 \\
332 ; 0.62 \\
781 ; 1.05\end{array}$ & $\begin{array}{c}3.4 \\
179 \\
14.1 \\
397 ; 0.74 \\
785 ; 1.05\end{array}$ & $\begin{array}{l}3.5 \\
157 \\
13.5 \\
327 ; 0.61 \\
699 ; 0.94\end{array}$ & $\begin{array}{l}3.0 \\
178 \\
14.5 \\
1468 ; 0.87 \\
4800 ; 1.09\end{array}$ & $\begin{array}{l}3.4 \\
175 \\
14.0 \\
342 ; 0.63 \\
799 ; 1.07\end{array}$ \\
\hline
\end{tabular}

${ }^{a}$ The following nozzle combinations were used: Tests 1 and 2 - MXHC plug, $\mathrm{HC} 65^{\circ}$ cap; Tests 3 and 4 - MXHC plug, $\mathrm{HC}^{\circ} \mathrm{cap}$; Tests 5 and 6 - MXHC plug, $\mathrm{HC} 50^{\circ}$ cap

${ }^{b}$ Measured at windbox, after in-duct auxiliary gas burner, in-duct burner was not operated during testing

$c$ Not measured

${ }^{d}$ Total combustion efficiency includes contribution from natural gas 
Table 8 (cont.). Summary of October 1992 Testing ${ }^{a}$

\begin{tabular}{|c|c|c|c|c|c|c|}
\hline Test Number & 7 & 8 & 9 & 10 & 11 & 12 \\
\hline Length of SCCWS Firing (hours) & 4 & 4.5 & 6 & 4 & 5 & 6 \\
\hline $\begin{array}{l}\text { Firing Rate (MM Btu/h) } \\
\text { Natural Gas } \\
\text { SCCWS } \\
\text { Total }\end{array}$ & $\begin{array}{l}6.0 \\
13.0 \\
19.0\end{array}$ & $\begin{array}{l}5.6 \\
13.0 \\
18.6\end{array}$ & $\begin{array}{l}6.0 \\
13.2 \\
19.2\end{array}$ & $\begin{array}{l}6.1 \\
13.6 \\
19.7\end{array}$ & $\begin{array}{l}6.1 \\
13.3 \\
19.4\end{array}$ & $\begin{array}{l}6.2 \\
13.1 \\
19.3\end{array}$ \\
\hline Gas Support (\%) & 31.4 & 32.0 & 31.1 & 30.8 & 31.3 & 31.9 \\
\hline $\begin{array}{l}\text { Air Preheater Temperatures }(\rho F) \\
\text { Combustion Air Inlet } \\
\text { Combustion Air Outlet } \\
\text { Flue Gas Inlet } \\
\text { Flue Gas Outlet }\end{array}$ & $\begin{array}{r}76 \\
366 \\
577 \\
357\end{array}$ & $\begin{array}{r}70 \\
357 \\
564 \\
349\end{array}$ & $\begin{array}{r}63 \\
358 \\
573 \\
352\end{array}$ & $\begin{array}{l}65 \\
366 \\
594 \\
362\end{array}$ & $\begin{array}{c}61 \\
355 \\
534 \\
348\end{array}$ & $\begin{array}{r}61 \\
363 \\
592 \\
360\end{array}$ \\
\hline Combustion Air Temperature $\left({ }^{C} \mathrm{~F}\right)^{b}$ & 344 & 336 & 337 & 343 & 337 & 338 \\
\hline Steam Flow $(\mathrm{lb} / \mathrm{h})$ & N.Mc & N.M. & N.M. & N.M. I & N.M. & N.M. \\
\hline Boiler Efficiency (\%) & 78.8 & 77.7 & 79.4 & 79.9 & 79.5 & 79.6 \\
\hline $\begin{array}{l}\text { Combustion Efficiency }(\%)^{d} \\
\text { Total } \\
\text { Coal }\end{array}$ & $\begin{array}{l}94.2 \\
92.1\end{array}$ & $\begin{array}{l}93.0 \\
90.2\end{array}$ & $\begin{array}{l}95.1 \\
93.2\end{array}$ & $\begin{array}{l}95.8 \\
94.2\end{array}$ & $\begin{array}{l}95.1 \\
93.2\end{array}$ & $\begin{array}{l}95.9 \\
94.3\end{array}$ \\
\hline Atomizing Air Pressure (psig) & 186 & 186 & 185 & 187 & 150 & 150 \\
\hline SCCWS Temperature $\left({ }^{\circ} \mathrm{F}\right)$ & 135 & 143 & 141 & 125 & 137 & 128 \\
\hline SCCWS Solids Loading (wt. \%) & 60.3 & 57.0 & 59.0 & 62.1 & 60.3 & 61.2 \\
\hline $\begin{array}{l}\text { Baghouse } \\
\text { Inlet Temperature }\left({ }^{\circ} \mathrm{F}\right) \\
\text { Outlet Temperature }\left({ }^{\circ} \mathrm{F}\right)\end{array}$ & $\begin{array}{l}339 \\
309\end{array}$ & $\begin{array}{l}336 \\
311\end{array}$ & $\begin{array}{l}340 \\
313\end{array}$ & $\begin{array}{l}346 \\
318\end{array}$ & $\begin{array}{l}335 \\
306\end{array}$ & $\begin{array}{l}341 \\
315\end{array}$ \\
\hline $\begin{array}{l}\text { Flue Gas Composition (dry basis) } \\
\mathrm{O}_{2}(\%) \\
\mathrm{CO}(\mathrm{ppm}) \\
\mathrm{CO}_{2}(\%) \\
\mathrm{SO}_{2}(\mathrm{ppm} ; \mathrm{lb} / \mathrm{MM} \mathrm{Btu}) \\
\mathrm{NO}_{x}(\mathrm{ppm} ; \mathrm{lb} / \mathrm{MM} \mathrm{Btu})\end{array}$ & $\begin{array}{c}3.2 \\
209 \\
14.2 \\
309 ; 0.57 \\
785 ; 1.03\end{array}$ & $\begin{array}{l}3.4 \\
178 \\
13.9 \\
\text { N.M. } \\
\text { N.M. }\end{array}$ & $\begin{array}{c}3.4 \\
164 \\
14.1 \\
337 ; 0.63 \\
800 ; 1.07\end{array}$ & $\begin{array}{l}3.5 \\
172 \\
14.2 \\
312 ; 0.59 \\
871 ; 1.18\end{array}$ & $\begin{array}{l}3.2 \\
169 \\
14.1 \\
346 ; 0.64 \\
827 ; 1.09\end{array}$ & $\begin{array}{l}3.7 \\
174 \\
13.5 \\
297 ; 0.56 \\
876 ; 1.19\end{array}$ \\
\hline
\end{tabular}

${ }^{a}$ The nozzle combination MXHC plug and $\mathrm{HC} 50^{\circ}$ cap was used for Tests 7-12

${ }^{b}$ Measured at windbox, after in-duct auxiliary gas burner; in-duct burner was not operated during testing

$c$ Not measured

${ }^{d}$ Total combustion efficiency includes contribution from natural gas 
MXHC and high capacity cap with a spray angle of $75^{\circ}\left(\mathrm{HC}^{\circ}\right)$ when firing SCCWS and natural gas at rates similar to Tests 1 and 2;

- Test 4 - Evaluate the effect of reduced atomizing air pressure (150 psig) when firing at conditions similar to Tests 1-3;

- Test 5-Determine the lowest level of natural gas support achievable when firing SCCWS at a rate of $\sim 19$ million $\mathrm{Btu} / \mathrm{h}$ with $150 \mathrm{psig}$ atomizing air pressure and the $\mathrm{MXHC}$ plug and high capacity plug with a $50^{\circ}$ spray angle $\left(\mathrm{HC} 50^{\circ}\right)$;

- Test 6 - Repeat of Test 3 except that the MXHC plug and $\mathrm{HC}^{\circ} 0^{\circ}$ cap were used;

- Tests 7 and 8 - Test 6 conditions were repeated;

- Tests 9 and 10 - Evaluate the effect of a diffuser plate (see Figure 11 and description below) on combustion performance when firing at conditions similar to Tests 6-8;

- Tests 11 and 12 - Repeat of Tests 9 and 10 except that 150 psig atomizing air pressure was used (compared to $186 \mathrm{psig}$ );

- Test 13 - Repeat of Tests 9 and 10; and

- Tests 14 and 15-Diffuser plate removed for direct comparison of combustion performance with that obtained in Test 13;

In an attempt to improve the combustion efficiency and reduce the level of natural gas support, tests were conducted in October evaluating different nozzle combinations, various atomizing air pressures, and the use of a diffuser plate. A diffuser plate was installed at the end of the nozzle to reduce the quantity of, and impart swirl to, the combustion air in the vicinity of the nozzle tip. Combustion efficiencies varied from $92-94 \%$ for the October series of tests. The conclusion from the testing, as of October 1992, was that the diffuser plate and atomizing air pressure did not affect the combustion efficiency. The October testirig, as compared to previous tests, did indicate however, that the atomizer angle affects combustion performance. Tests with the $\mathrm{HC} 65^{\circ}$ cap resulted in higher combustion performance.

\section{Alternative Atomizer Testing}

The combustion performance achieved, and level of natural gas support necessary for maintaining a stable flame, were not acceptable when using the atomizer that was provided with the boiler. Consequently, an alternative atomizer, which was of external-mix design, was tested. Figure 12 is a schematic diagram of the external mix atomizer.

Initial tests consisted of pumping water through the atomizer to determine optimum atomizer settings (i.e., atomizing air pressures, discharge opening clearances). This was followed by SCCWS testing in the boiler. Testing was conducted over a one week period, most of which was intermittent in nature; therefore, detailed mass and energy balances were not conducted. The results of the tests that were of sufficient length to perform mass and energy balances are summarized in Table 9. 


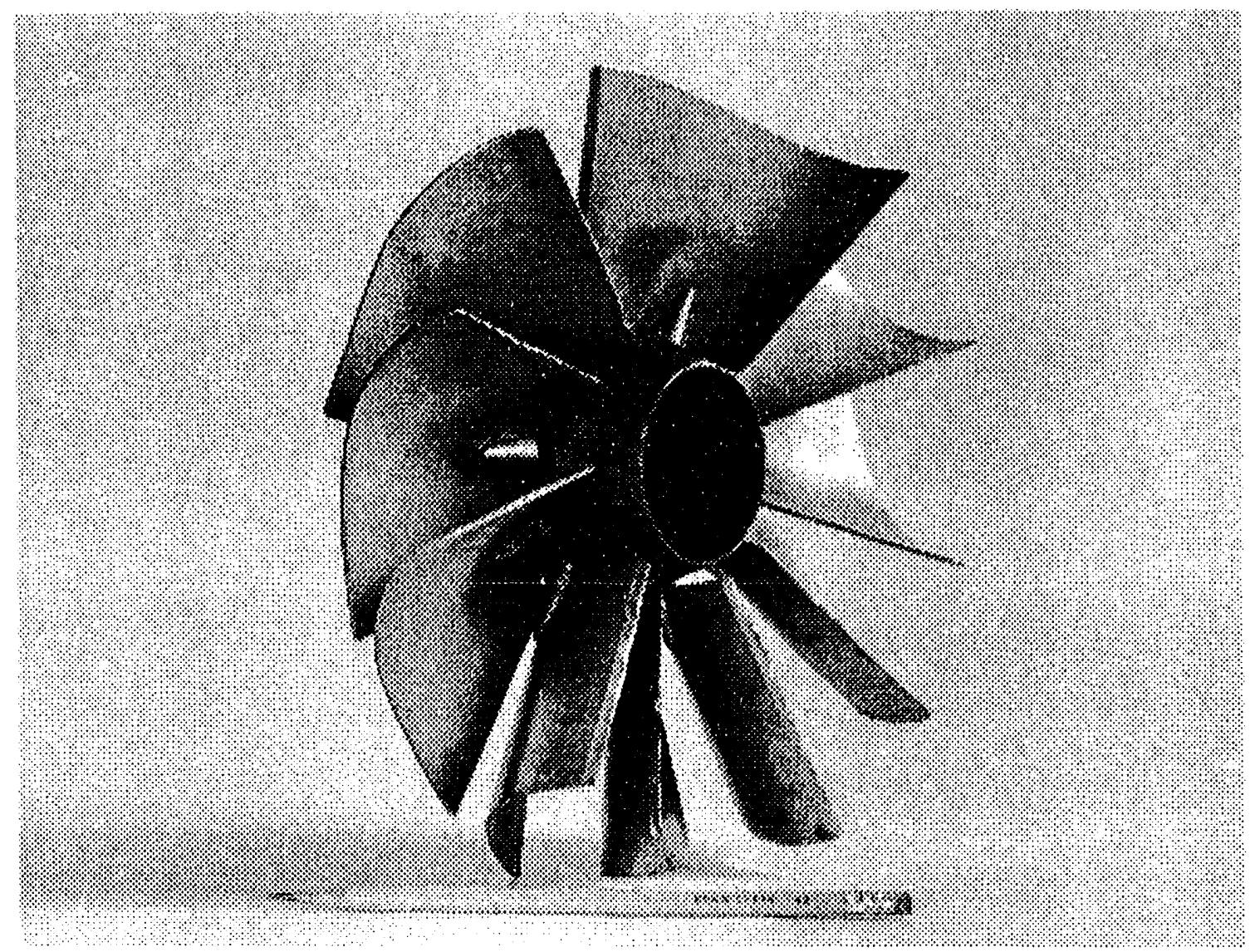

Figure 11. Photograph of the Diffuser Plate 


$$
\text { 孚 }
$$

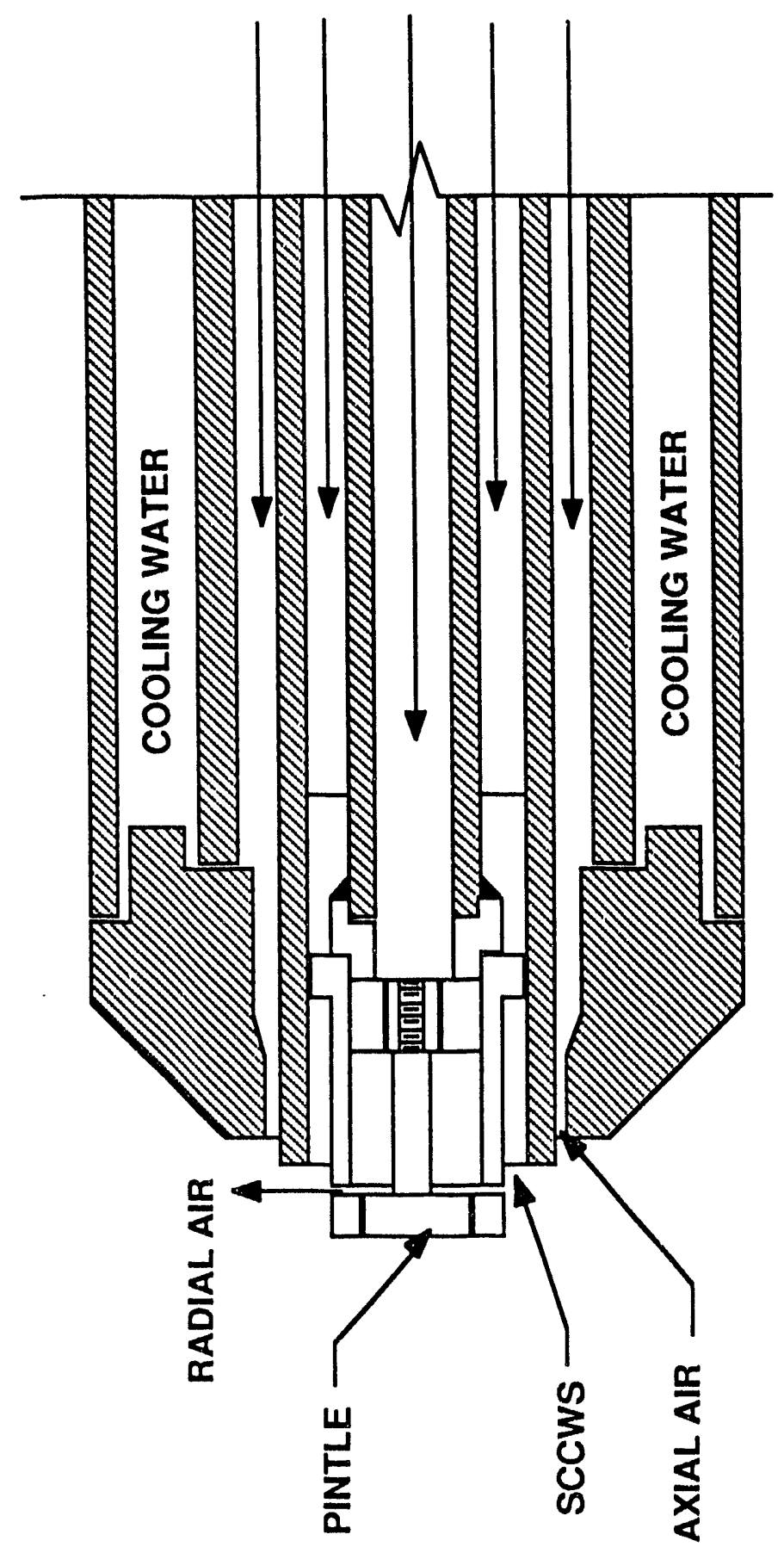

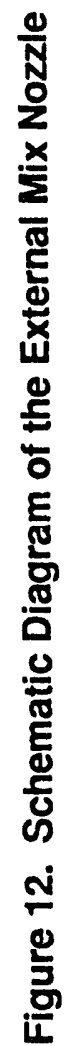


Table 9. Summary of Alternative Atomizer Testing

\begin{tabular}{|c|c|c|c|}
\hline Test Number & 1 & 2 & 3 \\
\hline Length of SCCWS Firing (hours) & 3 & 4 & 3.5 \\
\hline $\begin{array}{l}\text { Firing Rate }(\mathrm{MM} \mathrm{Btu} / \mathrm{h}) \\
\text { Natural Gas } \\
\text { SCCWS } \\
\text { Total }\end{array}$ & $\begin{array}{r}7.6 \\
12.5 \\
20.1\end{array}$ & $\begin{array}{l}6.0 \\
13.3 \\
19.3\end{array}$ & $\begin{array}{r}6.3 \\
13.0 \\
19.3\end{array}$ \\
\hline Gas Support (\%) & 37.7 & 31.3 & 32.4 \\
\hline $\begin{array}{l}\text { Air Preheater Temperatures }(F) \\
\text { Combustion Air Inlet } \\
\text { Combustion Air Outlet } \\
\text { Flue Gas Inlet } \\
\text { Flue Gas Outlet }\end{array}$ & $\begin{array}{l}48 \\
340 \\
566 \\
343\end{array}$ & $\begin{array}{r}54 \\
343 \\
559 \\
337\end{array}$ & $\begin{array}{l}63 \\
348 \\
554 \\
339\end{array}$ \\
\hline Combustion Air Temperature $\left({ }^{\circ} \mathrm{F}\right)^{a}$ & 326 & 319 & 329 \\
\hline Steam Flow $(\mathrm{lb} / \mathrm{h})$ & N.M. ${ }^{b}$ & N.M. & N.M. \\
\hline Boiler Efficiency (\%) & 74.0 & 75.2 & 77.4 \\
\hline $\begin{array}{l}\text { Combustion Efficiency }(\%)^{c} \\
\text { Total } \\
\text { Coal }\end{array}$ & $\begin{array}{l}88.4 \\
82.9\end{array}$ & $\begin{array}{l}89.3 \\
85.3\end{array}$ & $\begin{array}{l}92.5 \\
89.6\end{array}$ \\
\hline SCCWS Temperature $\left({ }^{\circ} \mathrm{F}\right)$ & 100 & 86 & 77 \\
\hline SCCWS Solids Loading (wt. \%) & 53.7 & 60.3 & 60.1 \\
\hline $\begin{array}{l}\text { Baghouse } \\
\text { Inlet Temperature }\left({ }^{\circ} \mathrm{F}\right) \\
\text { Outlet Temperature }\left({ }^{\circ} \mathrm{F}\right)\end{array}$ & $\begin{array}{l}336 \\
303\end{array}$ & $\begin{array}{l}326 \\
298\end{array}$ & $\begin{array}{l}327 \\
299\end{array}$ \\
\hline $\begin{array}{l}\text { Flue Gas Composition (dry basis) } \\
\mathrm{O}_{2}(\%) \\
\mathrm{CO}(\mathrm{ppm}) \\
\mathrm{CO}_{2}(\%) \\
\mathrm{SO}_{2}(\mathrm{ppm} ; \mathrm{lb} / \mathrm{MM} \mathrm{Btu}) \\
\mathrm{NO}_{\mathrm{x}}(\mathrm{ppm} ; \mathrm{lb} / \mathrm{MM} \mathrm{Btu}) \\
\end{array}$ & $\begin{array}{c}3.7 \\
144 \\
13.1 \\
320 ; 0.60 \\
\text { N.M. } \\
\end{array}$ & $\begin{array}{l}3.3 \\
166 \\
13.2 \\
312 ; 0.58 \\
\text { N.M. } \\
\end{array}$ & $\begin{array}{c}3.0 \\
152 \\
13.8 \\
333 ; 0.60 \\
\text { N.M. } \\
\end{array}$ \\
\hline
\end{tabular}

${ }^{a}$ Measured at windbox, after in-duct auxiliary gas burner; in-duct burner was not operated during testing

${ }^{b}$ Not measured

${ }^{c}$ Total combustion efficiency includes contribution from natural gas 
In summary, the atomizer, when operated at its optimum conditions, did not perform as well as the standard Faber oil atomizer when operated at its optirnum set of conditions. There were minor construction flaws observed which may have affected the atomizer performance. The atomizer was more adjustable when atomizing water than SCCWS. This is likely the result of the higher viscosity of the SCCWS, although viscosity/droplet size information was not available. Although the viscosity of the SCCWS was not measured every day, the viscosity of the $60 \mathrm{wt} . \%$ solids content slurry was $220 \mathrm{cp} @ 100 / \mathrm{s}$. The viscosity of the lower solids content SCCWS would be less than $220 \mathrm{cp}$.

It is possible that with further development, the atomizer performance might have been improved. It was not the goal of the testing to conduct developmental work. Therefore, a decision was made to terminate testing with the alternative atomizer and seek a commerciallydeveloped burner/nozzle/atomizer (Phase IV).

\section{November 1992}

In November, 22 hours firing SCCWS were accumulated with the Faber atomizer. Table 10 summarizes the results from the November testing. The objectives of the tests were:

- Tests 1 and 2 - Evaluate the effect of lower combustion air velocity (by removing some of the tiles in the burner throat to increase the diameter of the throat opening) and the use of the diffuser on combustion performance.

- Test 3-Determine the lowest level of natural gas support achievable with the lower gas velocity and diffuser plate removed.

The use of the diffuser plate did not improve combustion performance, in fact, its use in combination with the removed tile, caused flame/boiler control instability. Testing with the diffuser plate was terminated after Test 2 .

The last test of the program was with the diffuser plate removed and a reduced level of natural gas support. The lowest level of natural gas support achievable, while still maintaining a stable flame, was $\sim 15 \%$. The combustion and boiler efficiencies were $\sim 80$ and $96 \%$, respectively. This is the highest combustion efficiency that was achieved. The indications are that the reduced combustion air velocity (decreased by $\sim 36 \%$ to $136 \mathrm{ft} / \mathrm{s}$ ) had a positive effect on combustion performance.

\subsubsection{Subtask 1b. Slagging/Fouling Propensity; Corrosion Characteristics}

A probe was constructed and inserted into the demonstration boiler in June to obtain long-term information on convective pass deposition. Figures 13 through 15 show the location of the probe in the boiler and probe details. The probe is both water and air cooled and the tube temperature can be held constant at $<1,200^{\circ} \mathrm{F}$. The tube temperature was maintained at $450^{\circ} \mathrm{F}$ during the testing, a typical boiler tube temperature. The vertical portion of the probe is con- 
Table 10. Summary of November 1992 Testing $^{a}$

\begin{tabular}{|c|c|c|c|}
\hline Test Number & 1 & 2 & 3 \\
\hline Length of SCCWS Firing (hours) & 5.5 & 8 & 6 \\
\hline $\begin{array}{l}\text { Firing Rate (MM Btu/h) } \\
\text { Natural Gas } \\
\text { SCCWS } \\
\text { Total }\end{array}$ & $\begin{array}{r}5.8 \\
13.4 \\
19.2\end{array}$ & $\begin{array}{c}6.0 \\
13.1 \\
19.1\end{array}$ & $\begin{array}{c}2.8 \\
16.8 \\
19.6\end{array}$ \\
\hline Gas Support (\%) & 30.3 & 31.2 & 14.5 \\
\hline $\begin{array}{l}\text { Air Preheater Te mperatures }\left({ }^{\circ} \text { ) }\right. \\
\text { Combustion Air Inlet } \\
\text { Combustion Air Outlet } \\
\text { Flue Gas Inlet } \\
\text { Flue Gas Outlet }\end{array}$ & $\begin{array}{r}56 \\
355 \\
572 \\
351\end{array}$ & $\begin{array}{r}65 \\
365 \\
585 \\
360\end{array}$ & $\begin{array}{r}53 \\
360 \\
591 \\
362\end{array}$ \\
\hline Combustion Air Temperature $(\mathrm{C} F)^{b}$ & 334 & 341 & 338 \\
\hline Steam Flow $(\mathrm{lb} / \mathrm{h})$ & N.M.c & N.M. & N.M. \\
\hline Boiler Efficiency (\%) & 79.6 & 79.6 & 79.8 \\
\hline $\begin{array}{l}\text { Combustion Efficiency }(\%)^{\varphi} \\
\text { Total } \\
\text { Coal }\end{array}$ & $\begin{array}{l}95.4 \\
93.7\end{array}$ & $\begin{array}{l}95.8 \\
94.2\end{array}$ & $\begin{array}{l}96.2 \\
95.5\end{array}$ \\
\hline Atomizing Air Pressure (psig) & 186 & 186 & 186 \\
\hline SCCWS Temperature $\left({ }^{\circ} \mathrm{F}\right)$ & 115 & 123 & 131 \\
\hline SCCWS Solids Loading (wt. \%) & 60.9 & 61.0 & 61.1 \\
\hline $\begin{array}{l}\text { Baghouse } \\
\text { Inlet Temperature }\left({ }^{\circ} \mathrm{F}\right) \\
\text { Outlet Temperature }\left({ }^{\circ} \mathrm{F}\right)\end{array}$ & $\begin{array}{l}335 \\
300\end{array}$ & $\begin{array}{l}341 \\
312\end{array}$ & $\begin{array}{l}347 \\
318\end{array}$ \\
\hline $\begin{array}{l}\text { Flue Gas Composition (dry basis) } \\
\mathrm{O}_{2}(\%) \\
\mathrm{CO}(\mathrm{ppm}) \\
\mathrm{CO}_{2}(\%) \\
\mathrm{SO}_{2}(\mathrm{ppm} ; \mathrm{lb} / \mathrm{MM} \mathrm{Btu}) \\
\mathrm{NO}_{\mathrm{x}}(\mathrm{ppm} ; \mathrm{lb} / \mathrm{MM} \mathrm{Btu}) \\
\end{array}$ & $\begin{array}{c}3.7 \\
143 \\
14.3 \\
364 ; 0.69 \\
844 ; 1.15 \\
\end{array}$ & $\begin{array}{l}3.3 \\
143 \\
13.8 \\
407 ; 0.75 \\
\text { N.M. }\end{array}$ & $\begin{array}{c}3.6 \\
172 \\
15.0 \\
529 ; 1.02 \\
985 ; 1.36 \\
\end{array}$ \\
\hline
\end{tabular}

${ }^{a}$ The MXHC plug and $\mathrm{HC75}^{\circ}$ cap were used for the November testing; diffuser was used for Tests 1 and 2

${ }^{b}$ Measured at windbox, after in-duct auxiliary gas burner; in-duct burner was not operated during testing

$c$ Not measured

${ }^{d}$ Total combustion efficiency includes contribution from natural gas 


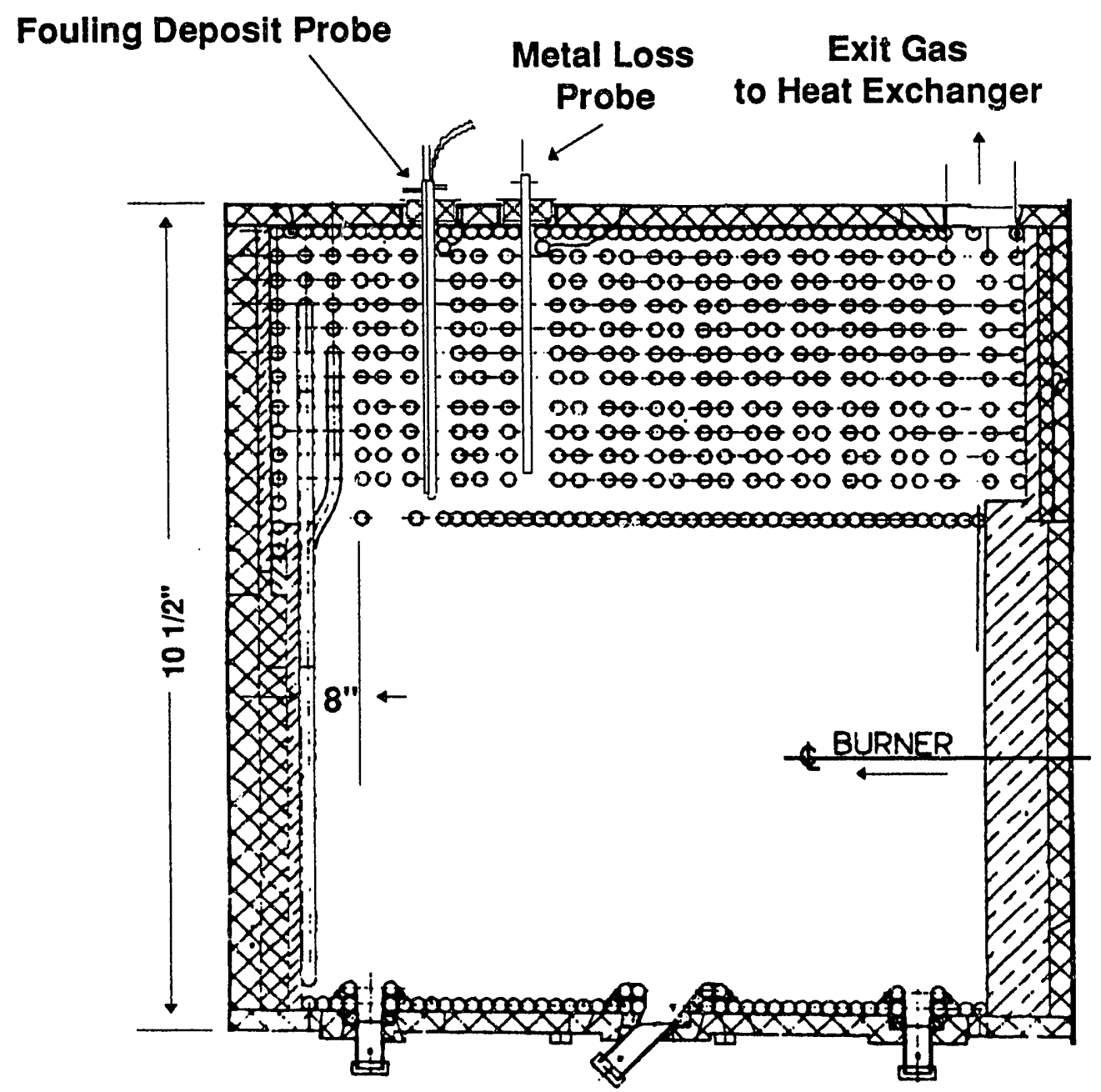

Figure 13. Plan View of Boiler Showing Location of the Deposition Probe (Plan view shows modifications to package boiler to accommodate additional sight ports and access for fouling $($. posit and metal loss probes.) 


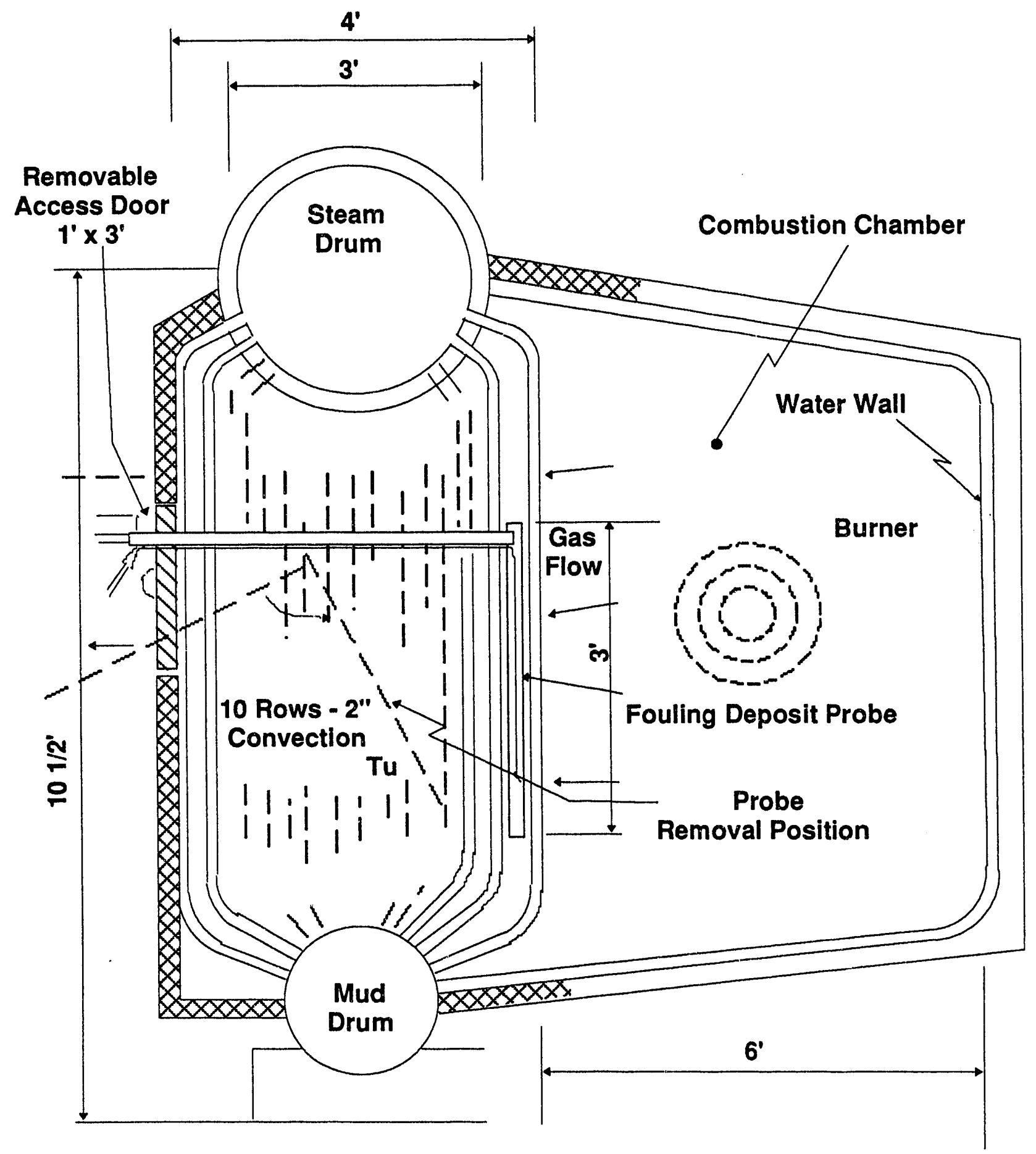

Dimensions Approximate

Figure 14. End View of Boiler Showing Location of the Deposition Probe 


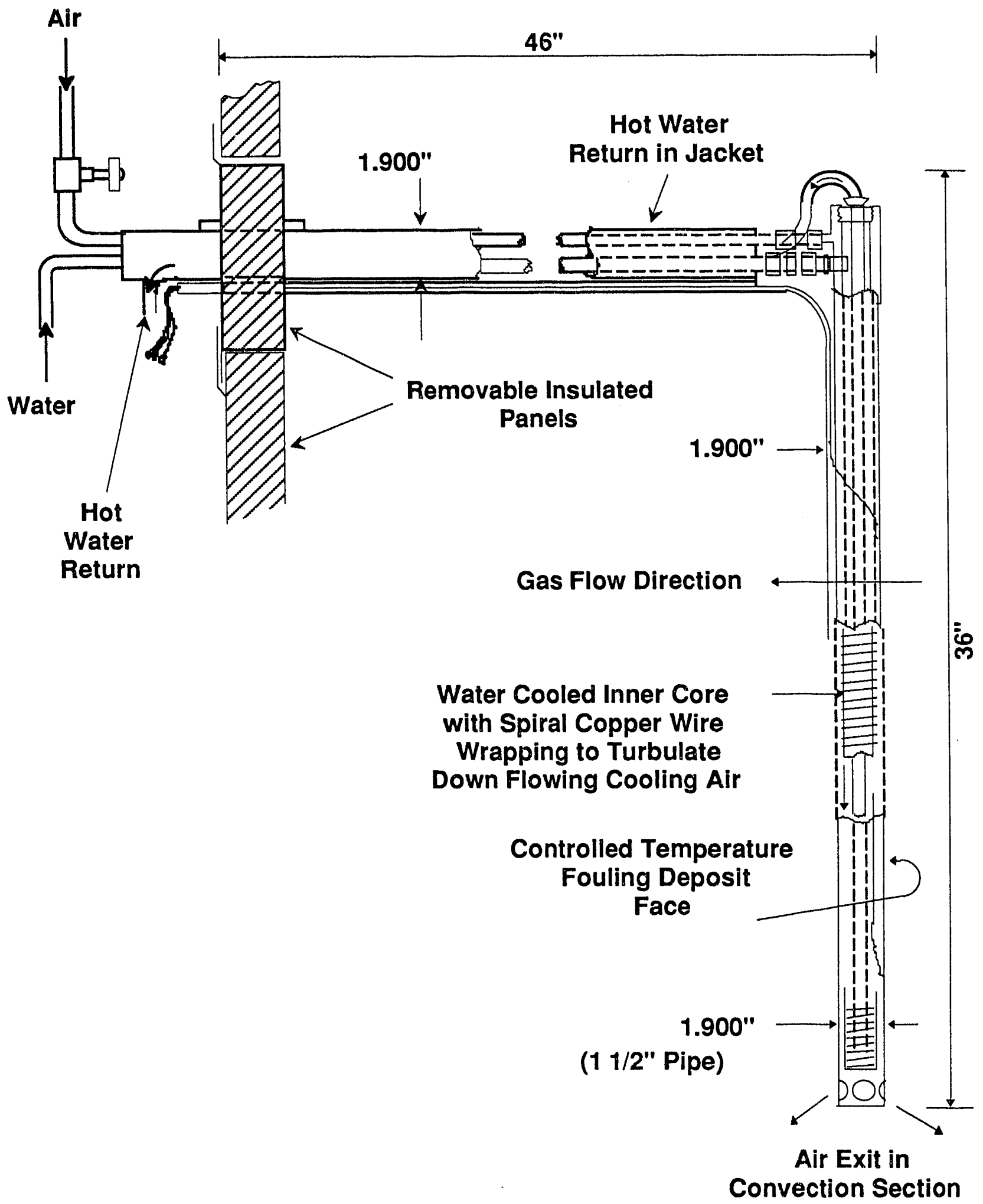

Figure 15. Details of the Deposition Probe 
structed of five replaceable test sections with various compositions. The length and composition of the test sections were: (1) 8" - SA178 conventional boiler steel; (2) 4" - 304 stainless steel; (3) 4" - 316 stainless steel; (4) 4" - plasma coated aluminum over a steel alloy; and (5) 4" - diffusion coated aluminum over a steel alloy.

The probe was inserted into the boiler for $\sim 126$ hours (June through August) without the formation of any sintered ash deposits. The probe was removed prior to the September testing because of a water leak in the cooling jacket and was not reinserted for the remainder of the testing. A thin, nonbinding ash and carbon coating was collected on the probe as a result of the low combustion efficiency obtained during the testing, the low ash content of the SCCWS, and the high ash fusion temperatures of the ash (initial deformation temperature $>2,800^{\circ} \mathrm{F}$ ).

\subsubsection{Subtask 1c. Erosion Characteristics}

Erosion measurements with a high velocity jet, as reported previously [6], indicated that ash deposition provided some protection against erosion. To evaluate the effect of ash deposition on the convective tubes at normal conditions, an air-cooled carbon steel tube was used as a probe during recent measurements in the demonstration boiler. The measurements were made while the boiler was cofiring SCCWS with natural gas at a firing rate of 18.6 million Btu/h. The gas temperature at the location of the probe was $900 \mathrm{~K}\left(1160^{\circ} \mathrm{F}\right)$ and the convective section gas velocity was $4.2 \mathrm{~m} / \mathrm{s}(14 \mathrm{ft} / \mathrm{s})$.

\section{Deposition Pattern}

When the probe was cooled to maintain its temperature at $450 \mathrm{~K}\left(350^{\circ} \mathrm{F}\right.$, temperature range from 350 to $710^{\circ} \mathrm{F}$ was investigated) and placed in the convective flow for 6 hours, the probe surface was covered by a layer of ash. Removal of the accumulated ash from 12 sectors covering the circumference of the probe showed an interesting pattern of deposition versus angle with respect to the flow direction. As shown in Figure 16, the deposit is very thin over almost the entire upstream half of the tube, is a maximum in the region from $90^{\circ}$ to $135^{\circ}$ away from the upstream stagnation line, and decreases again on the downstream side of the tube. This pattern shows the effect of impaction by incoming ash particles (upstream side) which removes deposited material, and that from diffusion of fine particles through the probe's boundary layer (downstream side).

\section{Growth of Deposit}

The growth of deposit on the metal surface at different temperatures was measured using 12 specimens cut from a carbon steel tube, machined on the outside of each test piece to produce a flat area $(12 \times 38 \mathrm{~mm})$, and mounted on the cutout portion of the probe. Both ends of the samples were wrapped with graphite, which provided a base for the measurement of their profiles. The samples were exposed to the flow on the upstream side of the probes for periods from 2 to 10 hours. After each test, the profile of the ash deposit was measured using a profilometer. 


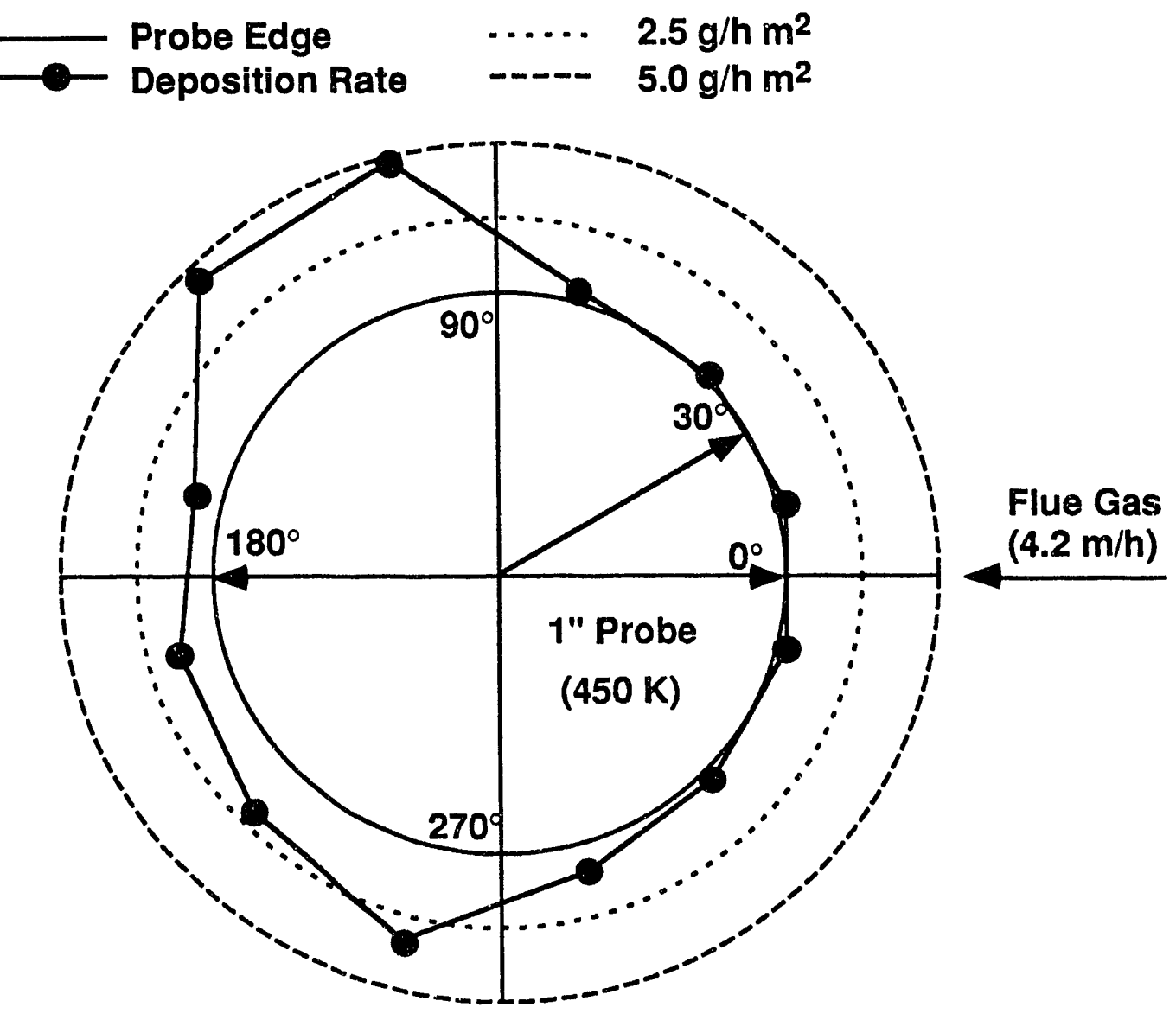

Figure 16. Deposition Pattern around the Probe Exposed to the Convective Flow of $4.2 \mathrm{~m} / \mathrm{h}$ for 6 Hours when the Air-Cooled Probe Was at $450 \mathrm{~K}$ 
Ash deposit was found over the surface of the specimen. The conditions at which measurements were made and the thicknesses of the deposits are given in Table 11.

The first series of measurements were made at the location where the center of the specimen was at an angle of $30^{\circ}$ from the upstream stagnation line of the probe. At the lowest temperature, $450 \mathrm{~K}\left(350^{\circ} \mathrm{F}\right)$, the ash deposit grew quickly. After a 10-hour test period, the deposit had a thickness of $800 \mathrm{~mm}(0.8 \mathrm{~mm})$. When the metal temperature was increased to $550 \mathrm{~K}$ $\left(530^{\circ} \mathrm{F}\right)$, deposition was still formed but its growth rate was lower than at $450 \mathrm{~K}$. At the highest temperature, $650 \mathrm{~K}\left(710^{\circ} \mathrm{F}\right)$, little growth of ash deposit was observed after a 2-hour test period and the deposit on the specimen surfaces was very thin. When the measurement location was moved to the upstream stagnation line $\left(0^{\circ}\right)$, similar amounts of ash deposit were found on the specimen at a given metal temperature after a 10-hour exposure as were observed at the first sample location.

Scanning electron micrographs of the deposit after exposure for 10 hours at different metal temperatures are shown in Figures $17 \mathrm{a}$ to $17 \mathrm{c}$. At the lowest temperature, $450 \mathrm{~K}$, the ash particle size in the deposit was up to $5 \mathrm{~mm}$, as shown in Figure 17a. With an increase in the metal temperature, there was a decrease in the particle size. As shown in Figures $17 \mathrm{~b}$ and 17c, the typical particle sizes were $3 \mathrm{~mm}$ for a metal temperature of $550 \mathrm{~K}$ and $1 \mathrm{~mm}$ for the highest temperature, $650 \mathrm{~K}$.

Preliminary measurements of cleanability were made using the small jet previously used for the erosion measurements. As shown in Figure 17d, the sample surface was cleaned by the jet at $200 \mathrm{~m} / \mathrm{s}$ for 30 minutes following a 5-hour exposure at a third location, the downstream stagnation line $\left(180^{\circ}\right)$, where the severe deposition occurred at $450 \mathrm{~K}$ as shown in Figure 16 . The ash deposit appears to be easily removable. The cleanability for the deposit formed at $550 \mathrm{~K}$ and $650 \mathrm{~K}$ was not measured. However, previous measurements on erosion by the high velocity jet indicated a deposit of 1-2 mm thickness remaining on the specimen that had been exposed to the same jet at temperatures of 550 and $650 \mathrm{~K}$ for 2 hours. Thus, the strength of the deposit bonding to the specimen at higher temperatures is expected to be stronger in spite of the negative dependence of the growth rate of deposit on temperature.

Certainly, the growth of ash deposits at relatively low temperatures is not simply related to the bonding strength between the ash particles and the metal (or oxide) substrate. In fact, when a monolayer of particle deposit has covered the surface of the substrate, the bonding strength is not the rate-determining factor for ash deposition. The negative dependence of deposition rate on the metal temperature is most likely due to the temperature gradient in the boundary layer. At a given gas temperature, the lower the metal temperature, the higher the temperature gradient within the boundary layer. The thermophoretic force, which causes diffusion toward the lower temperature region, is proportional to the temperature gradient. Hence, the growth rate of a 
Table 11. Measurements for the Carbon Steel Under Convective Section Conditions

\begin{tabular}{|c|c|c|c|}
\hline $\begin{array}{l}\text { Position of } \\
\text { Specimen }^{\mathrm{a}}\end{array}$ & $\begin{array}{l}\text { Test Period } \\
\text { (hour) }\end{array}$ & $\begin{array}{l}\text { Metal Temperature } \\
\text { (K) }\end{array}$ & $\begin{array}{c}\text { Deposit Thickness } \\
(\mu \mathrm{m})\end{array}$ \\
\hline $30^{\circ}$ & 2 & 450 & $2 \sim 4$ \\
\hline $30^{\circ}$ & 6 & 450 & $2 \sim 100^{b}$ \\
\hline $30^{\circ}$ & 10 & 450 & $\sim 800^{\mathrm{b}}$ \\
\hline $30^{\circ}$ & 2 & 550 & $1 \sim 3$ \\
\hline $30^{\circ}$ & 6 & 550 & $2 \sim 4$ \\
\hline $30^{\circ}$ & 10 & 550 & $3 \sim 30$ \\
\hline $30^{\circ}$ & 2 & 650 & $1 \sim 3$ \\
\hline $30^{\circ}$ & 6 & 650 & $1 \sim 4$ \\
\hline $30^{\circ}$ & 10 & 650 & $1 \sim 2$ \\
\hline $0^{\circ}$ & 10 & 450 & $\sim 500^{b}$ \\
\hline $0^{\circ}$ & 10 & 550 & $3 \sim 23$ \\
\hline $0^{\circ}$ & 10 & 650 & $1 \sim 3$ \\
\hline
\end{tabular}

The angle at the center of the specimen with respect to the upstream stagnation lines of the probe.

${ }^{b}$ The value was out of the range of measurement by the profilometer. 

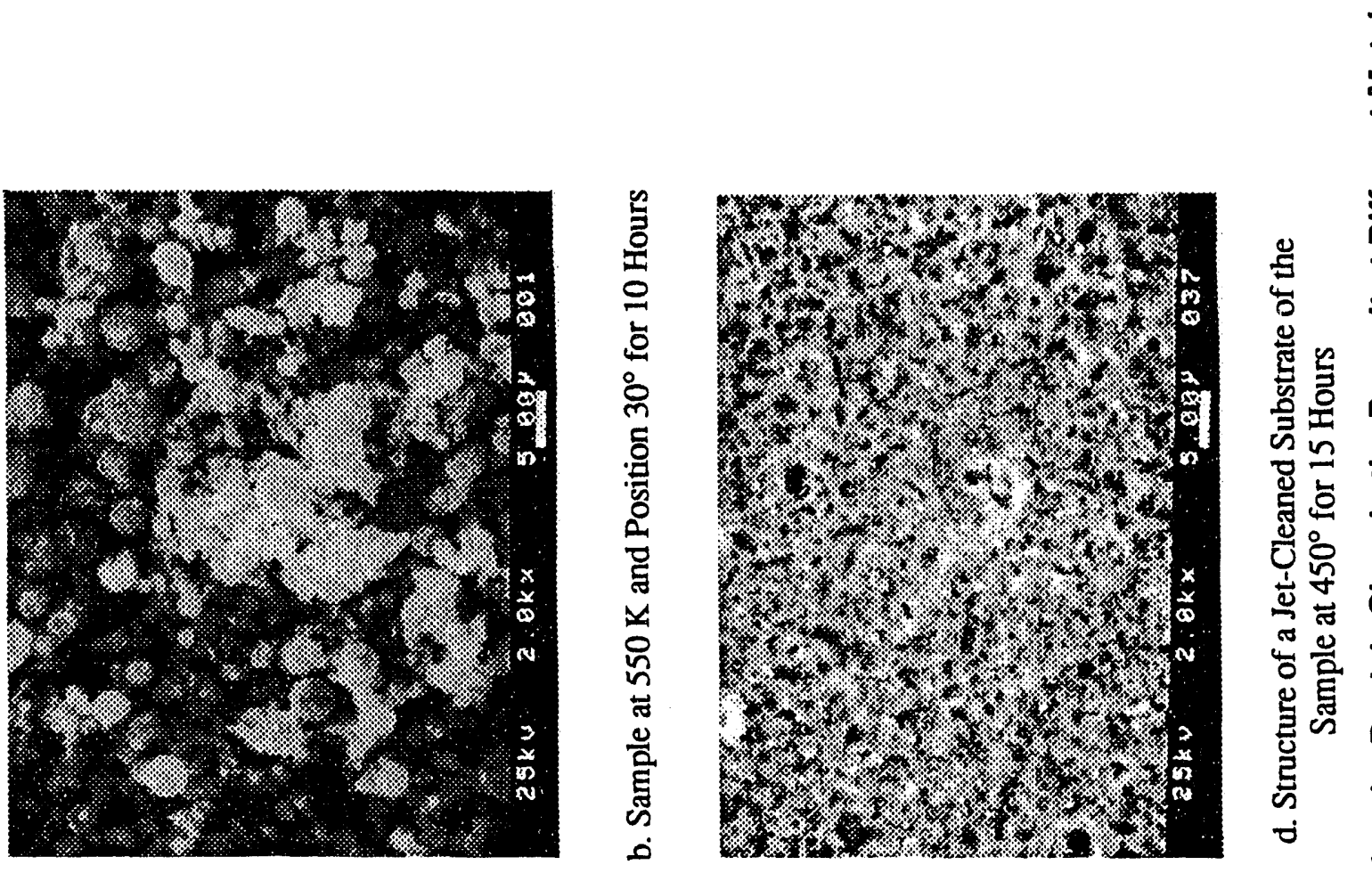

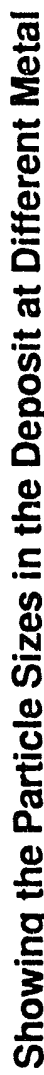
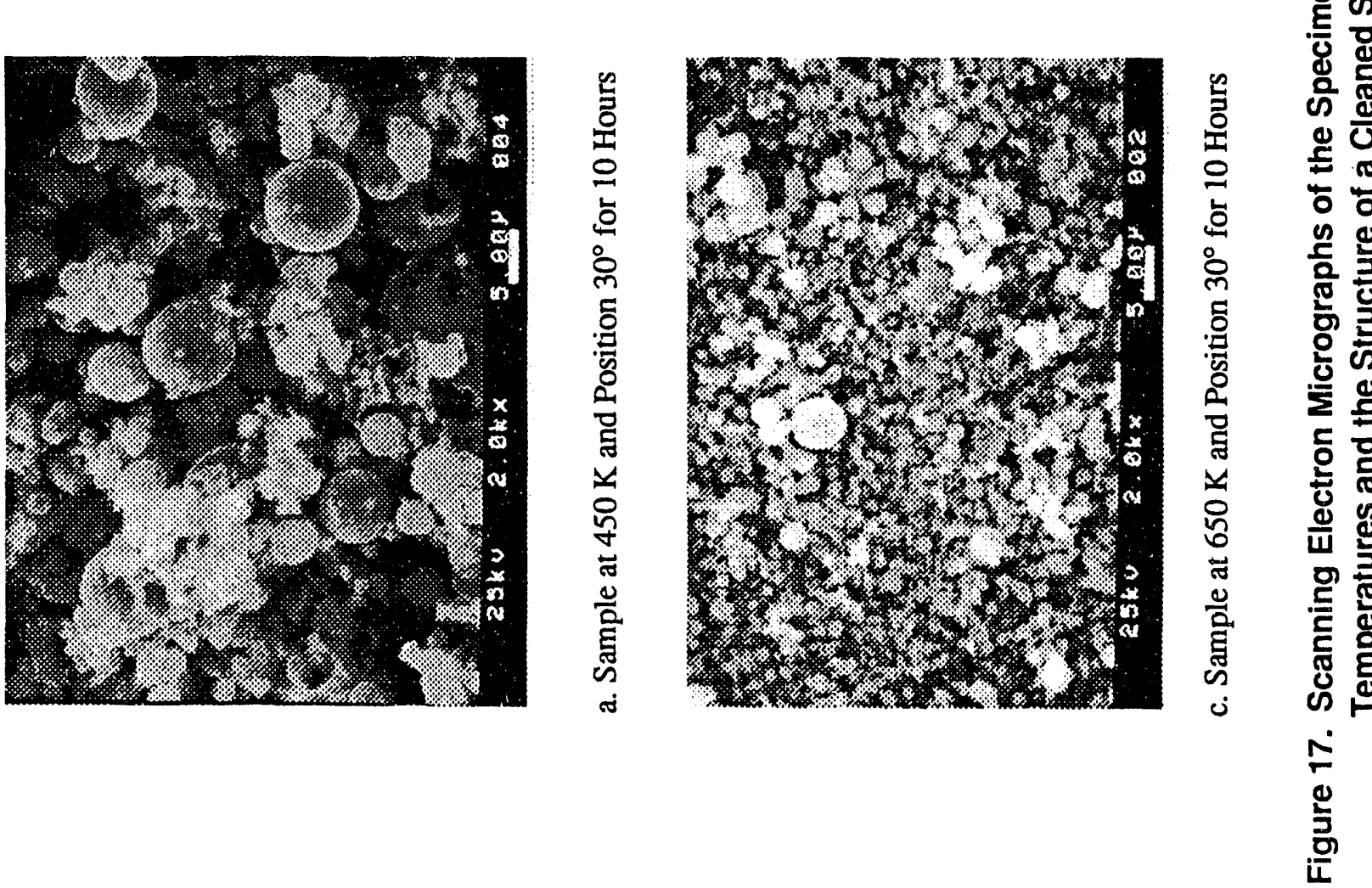
deposit depends on a balance between the thermal and Stokes' viscous drag forces within the boundary layer. As concluded by Raask [8], deposition by thermal diffusion becomes significant when the particle diameter is in the range of $0.5 \sim 5 \mathrm{~mm}$. This size range was exactly that found in the deposits formed during these measurements, as shown in Figures 17a to $17 \mathrm{c}$.

\section{Summary}

Ash deposition is favored by a relatively low convective velocity and high temperature gradient around a heat exchanger tube. At the highest metal temperature studied, $650 \mathrm{~K}$, and approach velocity of $4 \mathrm{~m} / \mathrm{s}$, the gas-metal temperature gradient was the lowest, so the ash deposit on the metal surface was thin and only a monolayer of ash particles was found to cover the oxidized metal surface. When a tube is covered by an ash deposit, erosion is not expected to be an important convective section problem associated with fly ash from coal-water fuel firing under normal operating conditions. However, the practical problem to be addressed is deciding what sootblowing frequency and jet blowing velocity are optimum to clean the ash deposits on the convective tubes, for a given fuel and convective conditions, in order to maximize heat transfer and minimize tube wastage (by the sootblowers) over long periods of operation.

\subsection{Task 2. Economic Evaluation}

In Task 2 a cost analysis was performed. The original objective of this task was to assess the economic viability of future fuel oil-to-coal retrofits by using the project's direct investment expenditures (e.g., material costs), construction costs, on-site modifications, start-up costs, and operating and maintenance costs. However, Penn State's demonstration facility was a not a field retrofit, rather it involved shop modification of a fuel oil-fired boiler and installation of it in a facility designed specifically for the boiler. In addition, the newly constructed facility included the installation of auxiliary components, such as the SCCWS preheater, baghouse, combustion air preheaters, storage tanks, and unloading station. Consequently, the analysis has been modified and assessments have been performed detailing costs for:

- retrofitting a natural-gas fired $15,000 \mathrm{lb}$ steam/h boiler to fire SCCWS at Penn State;

- two scenarios when retrofitting a fuel oil-fired $15,000 \mathrm{lb}$ steam/h boiler to fire SCCWS at Penn State.

- installing a facility at Penn State to produce $15,000 \mathrm{lb}$ steam/h firing SCCWS with research capabilities;

- installing a facility at Penn State to produce $15,000 \mathrm{lb}$ steam/h firing SCCWS (without research diagnostics):

- installing a facility at Penn State to produce $15,000 \mathrm{lb}$ steam/h firing fuel oil; and

- installing a facility at Penn State to produce $15,000 \mathrm{lb}$ steam/h firing natural gas.

The costs that were considered include materials and labor, fees, and contingencies.

They are actual expenditures and accurately reflect the costs necessary to either construct/install 
a new facility or retrofit an existing facility. An economic evaluation that determines payback time was not conducted because of the uncertainty of some operating costs such as fuel procurement. Costs that Penn State incurred in SCCWS procurement can not be used in an economic assessment. Penn State's operating costs were artificially high because of the nature of the program, i.e., research in nature, intermittent operation, and small-scale production quantities. Consequently, Penn State's costs are artificially high and will skew the results of an economic assessment if they are used. Other organizations have conducted studies estimating CWF costs based on a variety of assumptions and the results vary significantly. Because assumptions (especially SCCWS preparation costs and oil prices) greatly influence the final assessment, it was decided not to conduct a full economic assessment but instead provide the actual costs for installing a new facility or system retrofit in sufficient detail so that those interested in determining payback periods could do so by applying their estimates for fuel procurement (and other operating and maintenance costs), cost of capital, and replaced fuel cost.

The information that was used in the analysis included actual costs incurred by Penn State, estimates from CDA International, Inc., the engineering design firm, and engineering estimates. Actual costs included those from purchase order work, contractor costs, and costs of self completed projects. Detailed cost estimates compiled by CDA International, Inc. for the design effort were used when determining retrofit costs. In some cases, labor was estimated using sound engineering judgment with current costs of materials were used. Some costs, primarily those from CDA International, Inc., were not up-to-date and were reported on a 1992 dollar basis using Marshall \& Swift equipment cost indices and current business indicators [9]. When labor rate estimates were needed, those from Peters and Timmerhaus [10] were used. The cost analysis details are contained in Appendix A and are summarized below. Appendix A contains the details of the retrofit analyses (Cost Analysis Details - A), a spreadsheet calculating retrofit costs, a copy of CDA International, Inc.'s engineering estimates determined during the design of the demonstration facility, and details to the facility installation costs (Cost Analysis Details - B).

Table 12 and Figures 18 and 19 summarize the results from the cost analysis for the boiler retrofits and facility installations. The results of the retrofit cost analysis will be presented first, followed by the analysis of facility installations.

\section{Retrofit Cost Analysis}

The existing demonstration facility was divided into ten sections for the retrofit analysis. These are: 1) SCCWS storage tank, 2) unloading station, 3) day tank, 4) SCCWS preheater, 5) burner pump, 6) combustion air preheater/ducting modifications, 7) baghouse, 8) fans, 9) ash hopper, and 10) burner. The first eight items exist at the site while the last two will be installed at a later date. Costs were determined for retrofitting a natural gas-fired boiler and a fuel oilfired boiler with and without an oil preheater which could be used to preheat the SCCWS. Using 
Table 12. Cost Analysis Summary

Retrofit Costs to Convert Boilers to CWSF Firing

- Retrofit a natural gas-fired boiler

$\$ 763,332.80$

- Retrofit a fuel oil-fired boiler

-- assume SCCWS preheater must be installed

$\$ 679,764.59$

-- assume it has a fuel oil preheater for use

$\$ 669,651.58$

Cost of Installed Facilities at Penn State

- Cost of facility to conduct research firing CWSF

$\$ 1,905,260.28$

- Cost of facility to fire CWSF at Penn State for steam production

$\$ 1,667,188.45$

- Cost of facility to fire fuel oil at Penn State for steam production

$\$ 987,423.86$

- Cost of facility to fire natural gas at Penn State for steam production

$\$ 903,855.43$ 


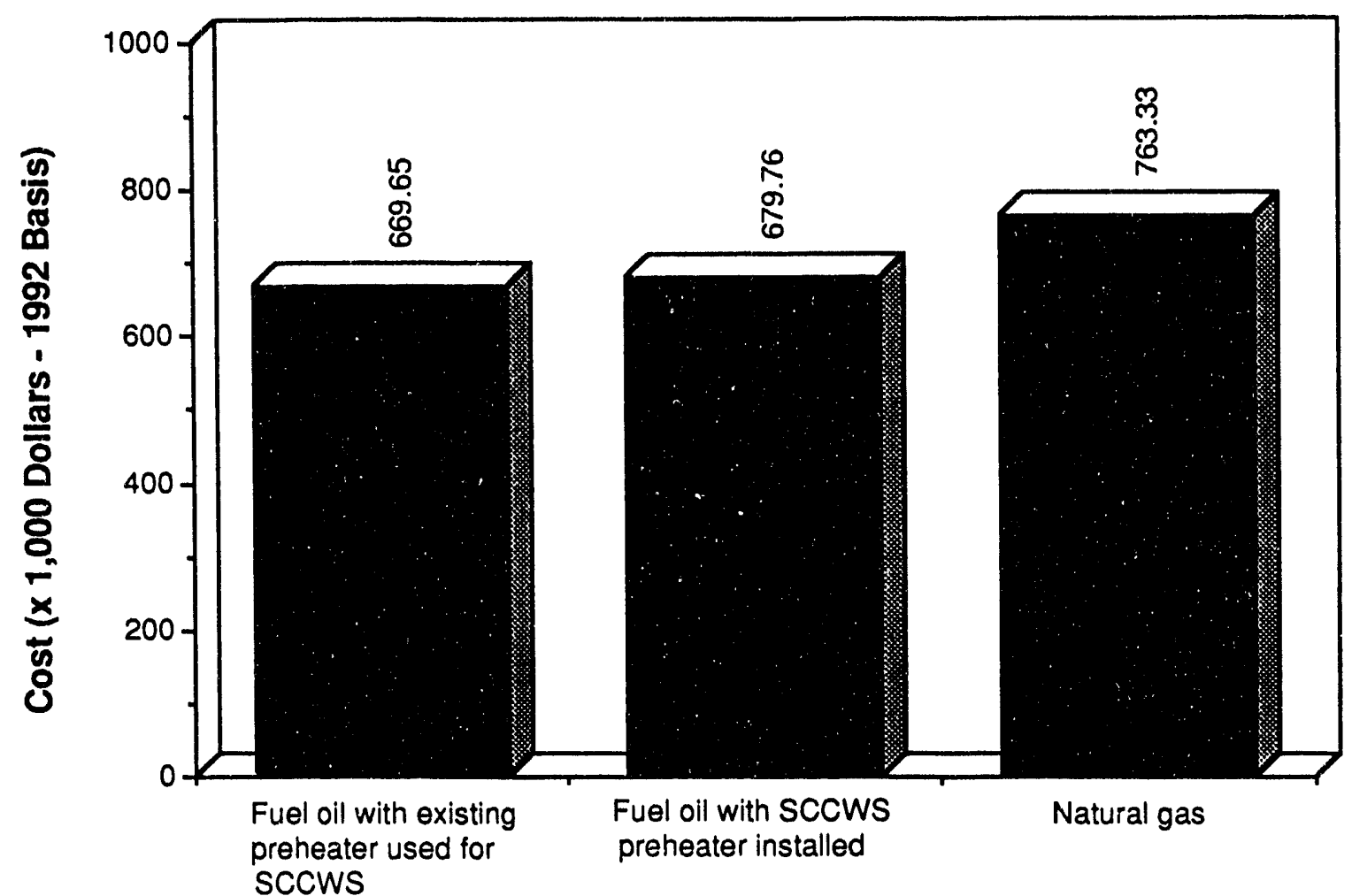

Boiler Type

Figure 18. Retrofit Costs of a $15,000 \mathrm{lb}$ Steam/h Boiler to Fire SCCWS at Penn State

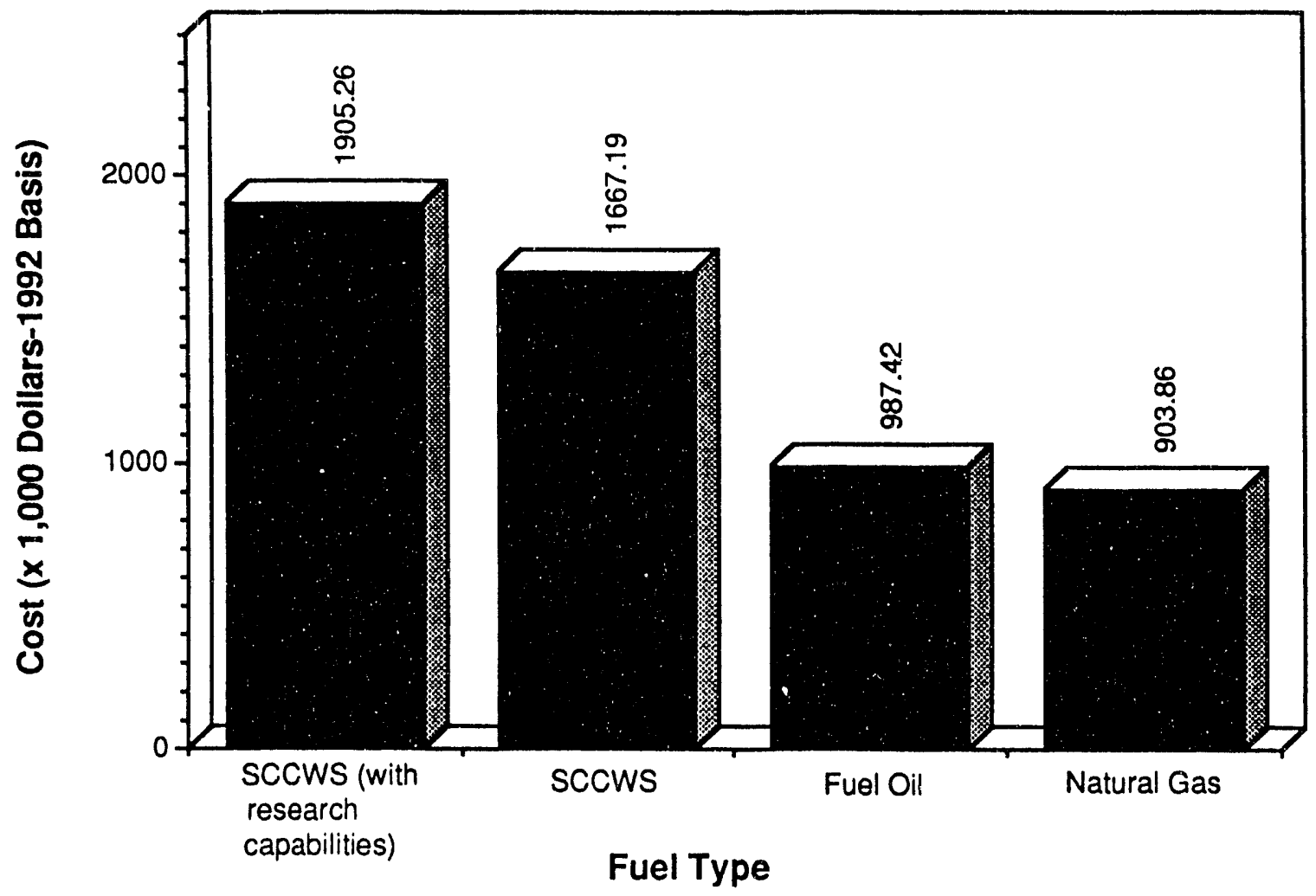

Figure 19. Cost of a Boiler System to Produce $15,000 \mathrm{lb}$ Steam $/ \mathrm{h}$ at Penn State as a Function of Fuel Type 
the cost sources discussed above, the costs for the ten retrofit areas were determined (in 1992 dollars). Following is a brief discussion of each retrofit area. Detailed calculations are given in Appendix A, Cost Analysis Details -A.

\section{SCCWS Storage Tank}

The cost for installing a 15,000-gallon storage tank was $\$ 63,932.67$. This included site work, the tank with embedded heaters, mixer, safety ladder and railings, and recirculation piping in the tank. Materials and labor were included for the equipment, equipment installation, electrical work, and site work.

\section{Unloading Station}

The cost for installing an unloading station was $\$ 30,119.03$. Items that were installed included an air-operated double diaphragm pump, pipe header system, concrete pad, protective enclosure and heater for the pump and header, piping to/from the storage tank, piping to the day tank, purge water piping, basket and strainer, and compressed air piping. Piping included pipe, insulation, valves, fittings, and trenching and heat tracing where applicable. All piping referenced in subsequent sections also included these items.

\section{Day Tank}

The cost for installing a 2,000-gallon day tank was $\$ 36,620.23$. This included the tank, ladder, mixer, strainer and baskets, piping to/from burner (the system has a SCCWS recycle loop), instrumentation, electrical work, and controls.

\section{SCCWS Preheater}

The cost for installing the tube-and-shell heat exchanger for preheating SCCWS was $\$ 9,690.41$. This includes the preheater, insulation, instrumentation, electrical work, and controls.

\section{Burner Pump}

The cost for installing the burner pump was $\$ 17,458.97$. This includes the Moyno progressive cavity, positive displacement pump, controls, electrical work, and instrumentation which primarily consisted of a micromotion meter for monitoring SCCWS flow.

\section{Combustion Air Preheater/Ducting Modifications}

The cost for installing a heat pipe heat exchanger to preheat the combustion air (using heat transferred from the flue gas), auxiliary in-duct gas burner, and ducting modifications was $\$ 99,139.28$. This included the heat pipe heat exchanger, ductwork and breeching (including expansion joints, support plates, etc.), insulation, controls, instrumentation, electrical work, and in-duct gas burner with associated materials.

\section{Baghouse}

The cost for installing the baghouse system was $\$ 151,612.40$. This included sitework (concrete, structural steel, brickwork, excavation), baghouse, insulation/sheeting, controls, electrical work, and instrumentation. 
electrical work, and instrumentation.

Fans

The cost for fans and fan modifications was $\$ 36,793.24$. Typically, boiler systems similar to the one at Penn State (15,000 lb steam/h fuel oil-designed) are operated in a forced draft mode. Therefore, costs were determined when the forced-draft system was converted to a balanced draft system. This included moving the forced draft (FD) fan from the boiler to upstream of the heat pipe heat exchanger, installing a forced draft fan, controls, instrumentation, and electrical work. Ducting modifications associated with moving the FD fan were included in the previous subsection.

\section{Ast Hopper}

The current system at Penn State is designed such that the fly ash is screw conveyed from the baghouse outlet to an ash truck as it is collected because the baghouse hopper has very little storage capacity. Consequently, the system is currently being modified to pneumatically transfer the fly ash from the baghouse outlet to a storage hopper that will be emptied periodically into an ash truck and transported to the disposal site. The cost for the ash hopper/removal system is $\$ 59,000$ which includes sitework (excavation, concrete, Office of Physical Plant (OPP) project management, and electrical work), hopper, blower, piping, filtering system, conditioning screw, controls, instrumentation, and electrical work.

\section{Burner}

As previously mentioned, the burner that is currently on the boiler does not perform satisfactorily. Therefore, the burner will be replaced for the next demonstration. A new burner system supplied in a retrofit will cost $\$ 106,300$. This includes the burner (nozzle and tips) and controls.

The total costs in the ten areas that have been addres $\quad l$ is $\$ 610,666.24$ (materials and labor). This does not include fees and contingency (factor of 1.25 of total cost) which raise the total to $\$ 763,332.80$. The fees and contingency rate was $25 \%$ of the total cost in the construction of Penn State's demonstration facility. This rate was used in the cost analysis. In summary, the cost to retrofit a natural gas-fired $15,000 \mathrm{lb}$ steam/h package boiler at Penn State to fire SCCWS is $\$ 763,332.80$. This assumes that the boiler does not require retubing, a reasonable assumption when low-ash coal is used.

The costs to retrofit a fuel oil-fired package boiler at Penn State to fire SCCWS was also determined. This was done for two scenarios: One where a preheater is installed for preheating the SCCWS (Scenario 1) and one where an oil preheater is available for use to preheat the SCCWS (Scenario 2). Detailed calculations are given in Appendix A, Cost Analysis Details -B.

In Scenario 1, each of the ten areas listed above (natural gas retrofit cost analysis) were 
required with modifications to the first three areas - storage tank, unloading station, and day tank. Modifications included:

1) A storage tank is available but requires electrical work and the installation of a mixer and recirculation piping.

2) The unloading station, which is assumed to originally be a connection point for a hose from a fuel truck, requires the installation of a pump/header system, concrete pad, protective enclosure/heater, piping from the storage tank to the pump (for recirculation), purge water piping, basket/strainer, and compressed air piping. It is assumed that piping is in place from the point of urioading to the storage tank and from the pump to the day tank (use the existing piping to the boiler).

3) The original system would not have a day lunk; therefore, a day tank with ladder and mixer, strainer/baskets, controls/electrical, and piping return to the day tank would have to be installed. It is assumed that the existing piping to the burner can be used.

The cost to retrofit a fuel oil-fired 15,000 lo steam/h package boiler at Penn State to fire SCCWS is $\$ 679,764.59$. This includes the addition of a heat exchanger to preheat the SCCWS.

In Scenario 2, the previous cost analysis was modified slightly by removing the cost of the preheater but not the cost for the instrumentation and controls which would require replacement for the new control system. The cost to retrofit a fuel oil-fired $15,000 \mathrm{lb}$ steam/h package boiler (with an existing preheater for the SCCWS) at Penn State to fire SCCWS is $\$ 669,651.58$ Facility Installation Cost Analysis

This section provides the actual costs incurred by Penn State to install a boiler system to provide $15,000 \mathrm{lb}$ steam/h firing SCCWS with research diagnostics. These costs are then compared to those for installing similar sized boilers for steam production when firing SCCWS (no research capabilities), natural gas or fuel oil. The results are shown in Figure 19 and discussed below.

\section{SCCWS-Fired Facility to Conduct Research}

The cost of the demonstration facility to conduct research firing SCCWS in a fuel oilfired boiler at Penn State is $\$ 1,698,635.28$. This reflects the cost to install a facility to produce $15,000 \mathrm{lb}$ steam/h where the entire facility is constructed. Detailed calculations are given in Appendix A, Cost Analysis Details -B. The cost includes construction contracts (Haranin Construction Co., KirCon-Breco, Inc., and G.M. McCrossin, Inc.), diagnostics, analyzers, computers, data acquisition system, process instrumentation, ash handling, and SCCWS handling and atomization. All of the items, except for the construction contracts, were installed/procured by Penn State during the execution of the first demonstration in the SCCWS program. As previously mentioned, the system is being modified prior to the second demonstration by the addition of an ash hopper and a new burner. Including the costs for these items brings the total to 
$\$ 1,905,260.28$. This is the value reported in Table 12 and Figure 19 because it better reflects what the actual system cost is.

\section{SCCWS-Fired Facility for Steam Production}

An evaluation was conducted to compare the cost of producing steam using different fuels. The cost to produce $15,000 \mathrm{lb}$ steam/h at Penn State firing SCCWS is $\$ 1,667,188.45$. This was determined by subtracting the diagnostics and instrumentation (except for the micromotion sensor) from the previous total.

\section{Fuel Oil-Fired Facility for Steam Production}

The cost to produce $15,000 \mathrm{lb}$ steam/h at Penn State firing oil is $\$ 987,423.86$. This was determined by subtracting the cost to retrofit an oil-fired facility to fire SCCWS from the cost of the SCCWS-fired facility.

\section{Natural Gas-Fired Facility for Steam Production}

The cost to produce $15,000 \mathrm{lb}$ steam/h at Penn State firing natural gas is $\$ 903,855.65$. This was determined by subtracting the cost to retrofit a natural gas-fired facility to fire SCCWS from the cost of the SCCWS-fired facility.

\subsection{Task 3. Complete Project Report}

The project report which details the results from Phases I-III was started this reporting period. The report will summarize the work conducted, and present conclusions reached, for each phase of work.

\subsection{ADVANCED SYSTEM TESTS}

\subsection{Task 1. Procure and Install Burner and Superheater}

As reported previously, requests for proposals to provide an advanced coal proven atomizer/nozzle/burner system were submitted to several boiler manufacturers and engineering firms [6]. Several proposals were received, reviewed, and one was selected in conjunction with DOE. The system, to be provided by ABB Combustion Engineering, has not been ordered yet because the second demonstration will not be conducted until early 1994 due to the construction of the SCCWS preparation facility and testing commitments under two other DOE and U.S. Department of Defense/DOE programs (Subcontract No. DOE-ABB-TPSU-91160-0001 from ABB Combustion Engineering under prime contract No. DE-AC22-91PC91160 and Cooperative Agreement No. DE-FC22-92PC92162).

Although the second demonstration will not be conducted until 1994, the superheater will be installed prior to boiler operation for the next test program (micronized coal testing for $\mathrm{ABB}$ Combustion Engineering). The superheater will be installed where the deposition probe is currently located. The deposition probe will not be used during the second demonstration. During this reporting period, work was initiated on the installation of the superheater and auxiliary components. Auxiliary components were identified, a flow diagram prepared, a tube weld- 
ing company selected to provide installation service, and Tampella Power Corporation was contacted to provide drawings and tube design specifications.

Figure 20 is the proposed flow diagram. The system will be constructed such that: steam flow can be regulated to maintain preset tube metal temperatures (thermocouples will be installed on the tube at various locations); steam quality, temperature, and pressure can be monitored; and heat flux to the tube measured. The test section will be composed of two or three sections consisting of different metal compositions. After extended periods of operation, the superheater will be removed and the test section cut out for detailed inspection and analysis. A new test section will be welded into place and the superheater reinserted.

\subsection{Task 2. Construction of a SCCWS Preparation Facility}

The construction of the SCCWS preparation facility began this reporting period. Figure 21 shows the overall site view with the location of the facility in relation to the demonstration boiler. A plan view of the facility showing the equipment layout is illustrated in Figure 22. The facility is nearing completion and equipment shakedown will occur during the next reporting period.

\subsection{Task 3. Install an Advanced Flue Gas Treatment System}

Some work was conducted on this task. Potential suppliers of flue gas treatment systems have been presenting options to DOE. Prior to giving DOE formal presentations, the potential suppliers have been requesting, and receiving, information from Penn State pertaining to the demonstration boiler.

Penn State initiated internal work requests (EFRC to Office of Physical Plant (OPP)) to begin investigating options for siting the potential system(s) adjacent to the boilerhouse.

\subsection{MISCELLANEOUS ACTIVITIES}

A paper was prepared and presented at the 1993 SME Annual Meeting and Exhibit at Reno, Nevada February 15-18, 1993. The title of the presentation was "Preparing Coal-Water Slurry Fuels from Bituminous Coal Sources," authored by Joel L. Morrison, Bruce G. Miller, and Alan W. Scaroni.

A paper was prepared for the National Association of Corrosion Engineers, Corrosion 93 to be held March 7-12, 1993. The title of the paper is "Erosion of Fly Ash and Deposition of Ash on Carbon Steel in the Convective Section of an Industrial Boiler," authored by Peter M. Walsh, Jiangyang Xie, Roger L. Poe, Bruce G. Miller, and Alan W. Scaroni.

Two papers are being prepared for the 18th International Conference on Coal Utilization and Fuel Systems to be held April 23-26, 1993 in Clearwater, Florida. They are:

- "Preparing and Handling Coal-Water Slurry Fuels: Potential Problems and Solutions" authored by Joel L. Morrison, Bruce G. Miller, Roger L. Poe, and Alan W. Scaroni; and 


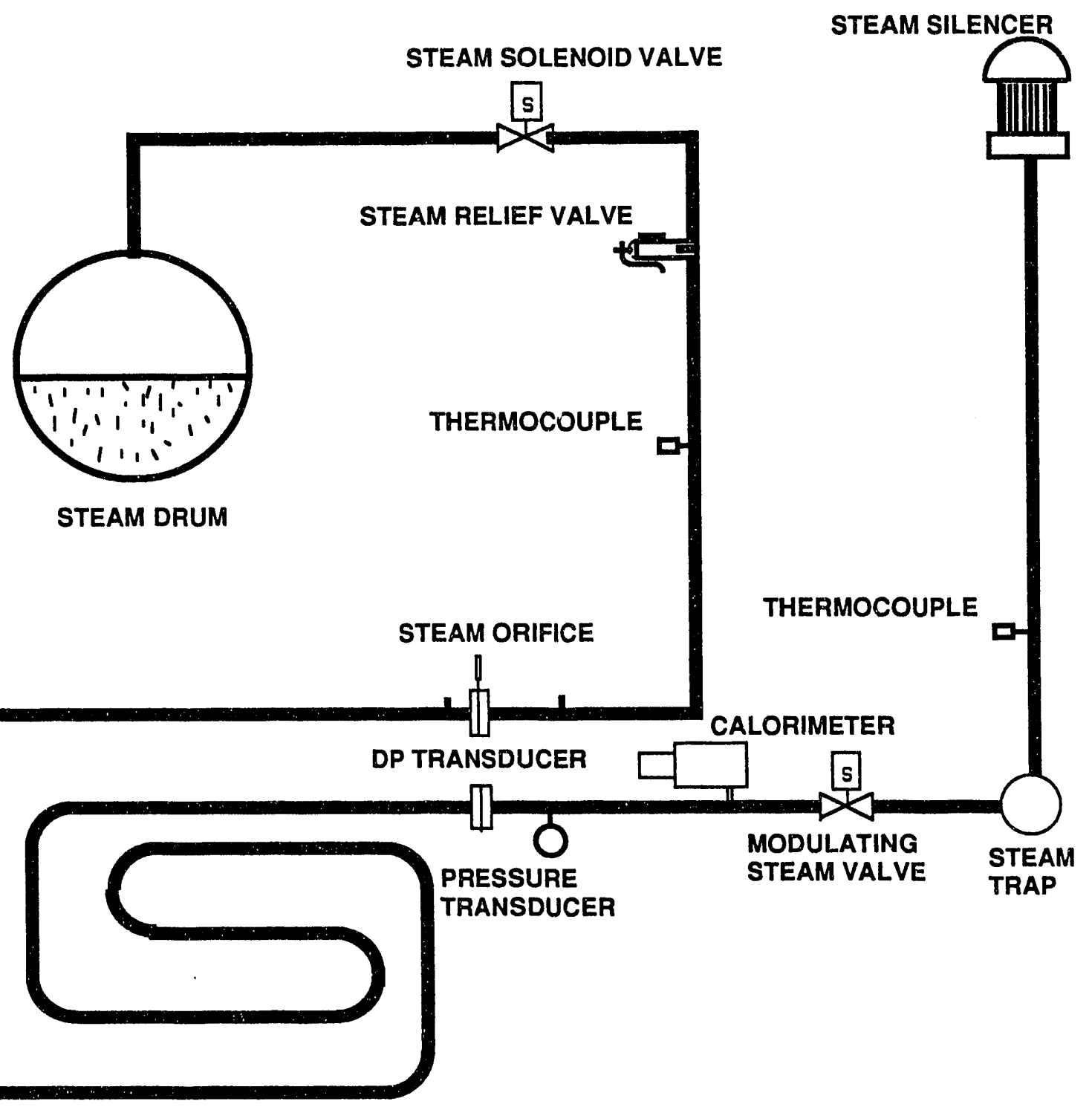

SUPERHEATER COIL

Figure 20. Superheater Flow Diagram 


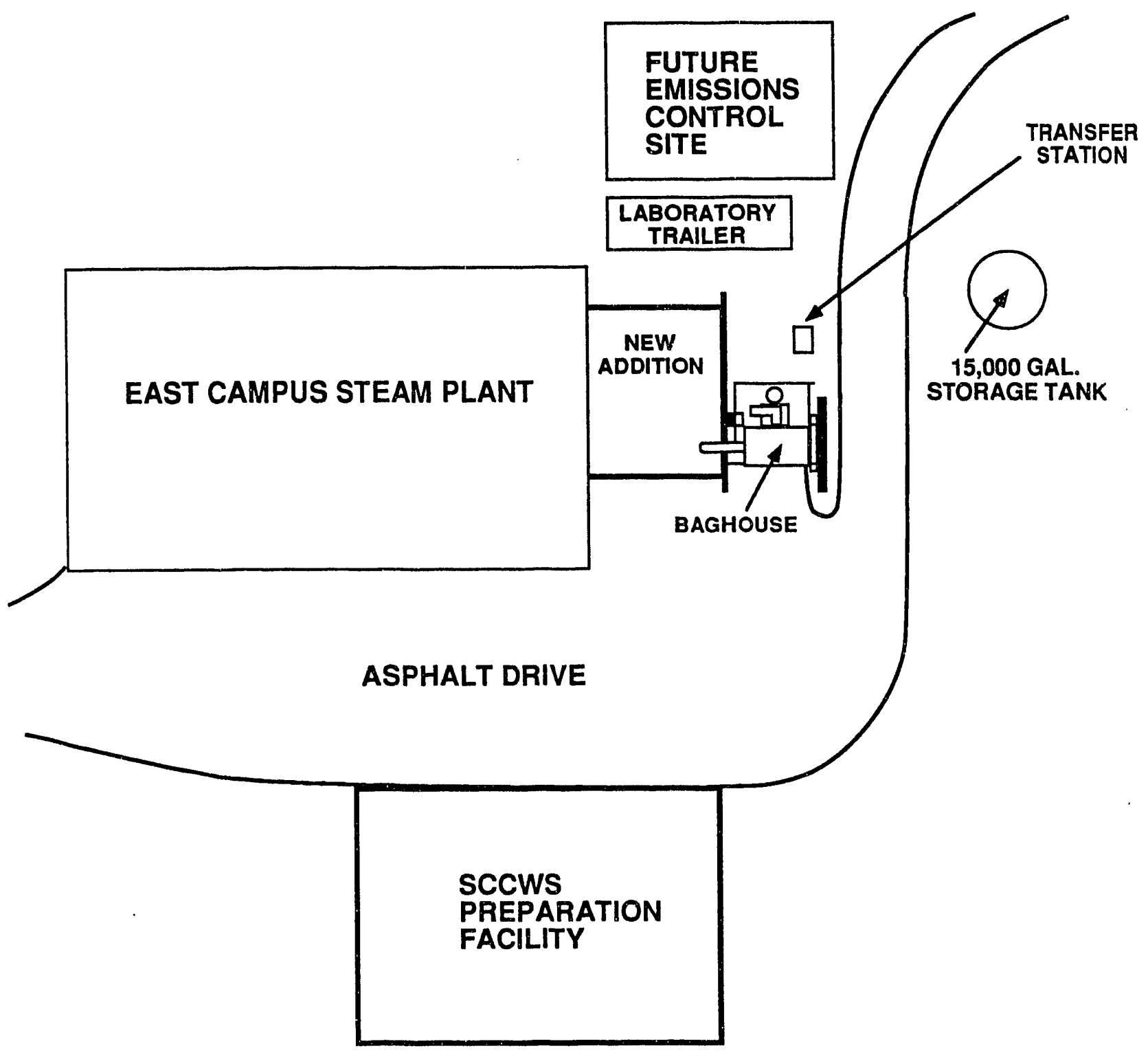

Figure 21. Overall Site View Showing the Location of the SCCWS Preparation Facility and Future Emissions Control Site 


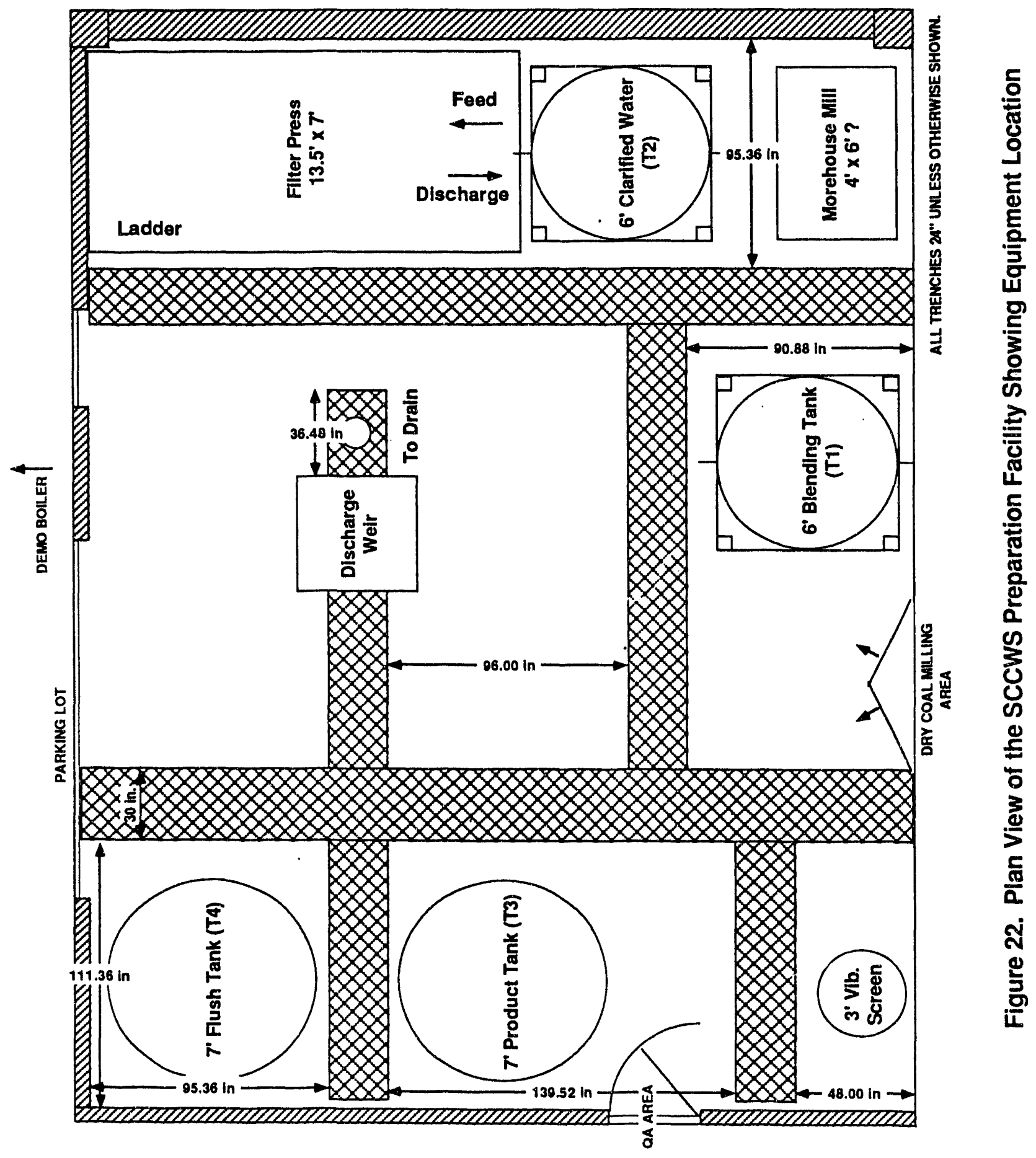


- "Combustion Performance of a Coal-Water Slurry Fuel in an Off-the-Shelf 15,000 lb Steam/h Oil-Fired Industrial Boiler" authored by Sarma V. Pisupati, Bruce G. Miller, and Alan W. Scaroni.

\subsection{NEXT SEMIANNUAL PERIOD ACTIVITIES}

During the next reporting period, the following will be completed:

- Project report for Phases I-III;

- Construction and shakedown of the SCCWS preparation facility;

- Installation of the superheater;

- Preparatory work for the installation of the flue gas treatment system(s) which includes obtaining permission from OPP for land usage and tying into the necessary utilities (water, electricity, and compressed air), site work, pouring a concrete pad, and running utilities to the test pad.

\subsection{REFERENCES}

[1] Kinneman, W.P., R.T. Wincek, B.G. Miller, A.W. Scaroni, and R.G. Jenkins, "Conversion of a $1000 \mathrm{lb} / \mathrm{h}$ Steam Boiler to Fire Coal Water Slurry Fuel," Thirteenth Int. Conf. on Coal and Slurry Tech., Denver, Colorado, p.725 (April 12-15, 1988).

[2] Miller, B.G., R.T. Wincek, A.W. Scaroni, W.P. Kinneman, and R.G. Jenkins, "Combustion of CWSF in a $1000 \mathrm{lb}$ Steam $/ \mathrm{h}$ Watertube Boiler," Thirteenth Int. Conf. on Coal and Slurry Tech., Denver, Colorado, p. 119 (April 12-15, 1988).

[3] Wincek, R.T., W.P. Kinneman, B.G. Miller, A.W. Scaroni, D. Shefet, and F. Kal, "Combustion Control System for a Coal-Water Slurry Fuel-Fired Boiler," AlChE Spring National Meeting, Houston, Texas (April 2-6, 1989).

[4] Miller, B.G., J.L. Morrison, J.T. Elston, P.M. Walsh, H.H. Schobert, and A.W. Scaroni, "Superclean Coal-Water Slurry Combustion Testing in an Oil-Fired Boiler," Semiannual Technical Progress Report for the Period 08/15/1990 to 02/15/1991, Pittsburgh Energy Technology Center, Pittsburgh, Pennsylvania, May 15, 1991, DE-FC22-89PC88697.

[5] Miller, B.G., R.L. Poe, J.L. Morrison, J. Xie, P.M. Walsh, H.H. Schobert, and A.W. Scaroni, "Superclean Coal-Water Slurry Combustion Testing in an Oil-Fired Boiler," Semiannual Technical Progress Report for the Period 08/15/1991 to 02/15/1992, Pittsburgh Energy Technology Center, Pittsburgh, Pennsylvania, May 29, 1992, DE-FC22-89PC88697.

[6] Miller, B.G., S.V. Pisupati, R.L. Poe, J.L. Morrison, J. Xie, P.M. Walsh, S. Shamanna, H.H. Schobert, and A.W. Scaroni, "Superclean Coal-Water Slurry Combustion Testing in an Oil-Fired Boiler," Semiannual Technical Progress Report for the Period 02/15/1992 to 08/15/1992, Pittsburgh Energy Technology Center, Pittsburgh, Pennsylvania, October 13, 1992, DE-FC22-89PC88697.

[7] Miller, B.G., J.L. Morrison, J. Xie, P.M. Walsh, H.H. Schobert, and A.W. Scaroni, "Super- 
clean Coal-Water Slurry Combustion Testing in an Oil-Fired Boiler," Semiannual Technical Progress Report for the Period 02/15/1991 to 08/15/1991, Pittsburgh Energy Technology Center, Pittsburgh, Pennsylvania, October 1, 1991, DE-FC22-89PC88697.

[8] Raask, E., "Mineral Impurities in Coal Combustion", Hemisphere Publishing Corporation, pp.189-199 (1985).

[9] Chemical Engineering, Volume 99, No. 10, p. 214 (1992).

[10] Peters, M.S., and K.D. Timmerhaus, Plant Design and Economics for Chemical Engineers, McGraw Hill Publishing Company, p. 875 (1980).

\subsection{ACKNOWLEDGMENTS}

The authors wish to acknowledge the following personnel for their contributions to the project during this reporting period:

- Scott A. Britton - Research Assistant

- Howard Glunt - Research Technician

- Ruth Krebs - Research Assistant

- Carl Martin - Laboratory Mechanic

- Ronald S. Wasco - Wage Payroll Assistant 

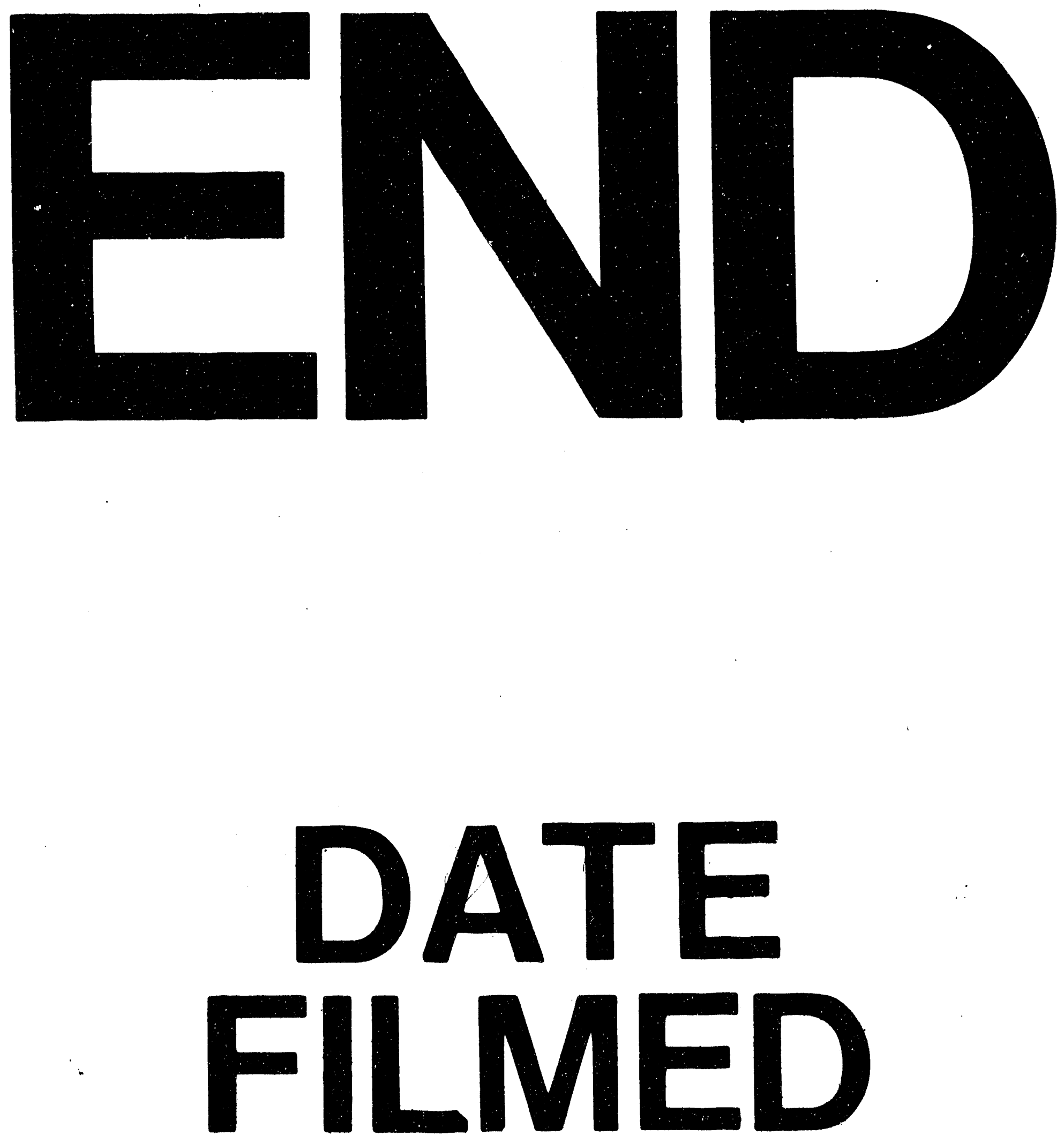

1

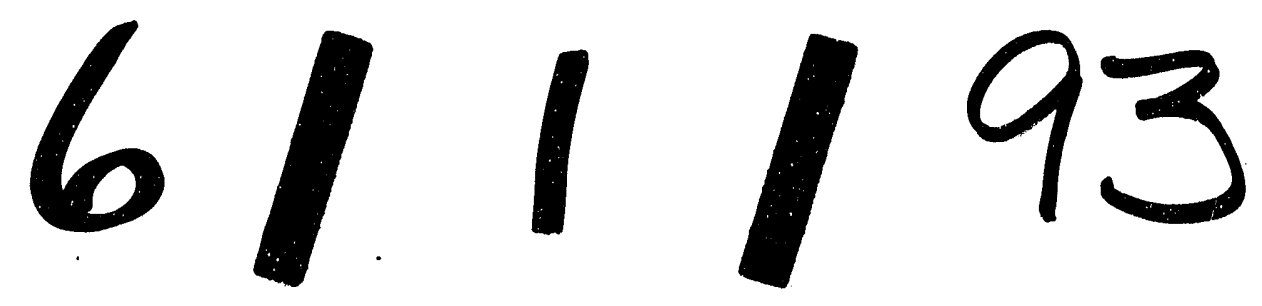


